\title{
Oncogene-Addicted Non-Small-Cell Lung Cancer: Treatment Opportunities and Future Perspectives
}

\author{
Miriam Grazia Ferrara ${ }^{1,2}$, Vincenzo Di Noia ${ }^{2,3}$, Ettore $D^{\prime}$ Argento $\left.{ }^{1,2}{ }^{(}\right)$, Emanuele Vita ${ }^{1,2}{ }^{(}$, \\ Paola Damiano ${ }^{1,2}$, Antonella Cannella ${ }^{1,2}$, Marta Ribelli ${ }^{1,2}$, Sara Pilotto ${ }^{4}$, Michele Milella ${ }^{4}$, \\ Giampaolo Tortora ${ }^{1,2}$ and Emilio Bria ${ }^{1,2, * \text { (D) }}$ \\ 1 Medical Oncology, Comprehensive Cancer Center, Fondazione Policlinico Universitario Agostino Gemelli \\ IRCCS, Università Cattolica del Sacro Cuore, 00168 Rome, Italy; miriamgraziaferrara@gmail.com (M.G.F.); \\ ettore.dargento@policlinicogemelli.it (E.D.); dr.emanuele.vita@gmail.com (E.V.); \\ paoladamiano88@gmail.com (P.D.); cannella.antonella@libero.it (A.C.); marta.ribelli@gmail.com (M.R.); \\ giampaolo.tortora@unicatt.it (G.T.) \\ 2 Medical Oncology, Università Cattolica del Sacro Cuore, 00168 Rome, Italy; vincedinoia@gmail.com \\ 3 Medical Oncology, Oncologia medica, Humanitas Gavazzeni, 24125 Bergamo, Italy \\ 4 Medical Oncology, Azienda Ospedaliera Universitaria Integrata, University and Hospital Trust of Verona, \\ 37126 Verona, Italy; sara.pilotto@univr.it (S.P.); michele.milella@univr.it (M.M.) \\ * Correspondence: emilio.bria@unicatt.it; Tel.: +39-06-30154277; Fax: +39-06-30154838
}

Received: 29 February 2020; Accepted: 3 May 2020; Published: 8 May 2020

check for updates

\begin{abstract}
Before the introduction of tyrosine kinase inhibitors (TKIs) for a particular subgroup of patients, despite platinum-based combination chemotherapy, the majority of patients affected by non-small-cell lung cancer (NSCLC) did not live longer than one year. With deeper understanding of tumor molecular biology, treatment of NSCLC has progressively entered the era of treatment customization according to tumor molecular characteristics, as well as histology. All this information allowed the development of personalized molecular targeted therapies. A series of studies have shown that, in some cases, cancer cells can grow and survive as result of the presence of a single driver genomic abnormality. This phenomenon, called oncogene-addiction, more often occurs in adenocarcinoma histology, in non-smokers (except BRAF mutations, also frequent in smoking patients), young, and female patients. Several different driver mutations have been identified and many studies have clearly shown that upfront TKI monotherapy may improve the overall outcome of these patients. The greater efficacy of these drugs is also associated with a better tolerability and safety than chemotherapy, with fewer side effects and an extremely good compliance to treatment. The most frequent oncogene-addicted disease is represented by those tumors carrying a mutation of the epidermal growth factor receptor (EGFR). The development of first, second and third generation TKIs against EGFR mutations have dramatically changed the prognosis of these patients. Currently, osimertinib (which demonstrated to improve efficacy with a better tolerability in comparison with first-generation TKIs) is considered the best treatment option for patients affected by NSCLC harboring a common EGFR mutation. EML4-ALK-driven disease (which gene re-arrangement occurs in 3-7\% of NSCLC), has demonstrated to be significantly targeted by specific TKIs, which have improved outcome in comparison with chemotherapy. To date, alectinib is considered the best treatment option for these patients, with other newer agents upcoming. Other additional driver abnormalities, such as ROS1, BRAF, MET, RET and NTRK, have been identified as a target mirroring peculiar vulnerability to specific agents. Oncogene-addicted disease typically has a low early resistance rate, but late acquired resistance always develops and therefore therapy needs to be changed when progression occurs. In this narrative review, the state of art of scientific literature about targeted therapy options in oncogene-addicted disease is summarized and critically discussed. We also aim to analyze future perspectives to maximize benefits for this subgroup of patients.
\end{abstract}


Keywords: oncogene; addiction; EGFR; ALK; ROS1; lung

\section{Oncogene Addiction}

Non-small-cell lung cancer (NSCLC) is the main cause of cancer-related deaths worldwide [1]. Before introducing tyrosine kinase inhibitors (TKIs), the overall survival (OS) of most patients with advanced NSCLC receiving platinum-based combination chemotherapy was less than one year [2]. The identification of molecular aberrations leading to tumor growth and survival, so-called oncogene-addicted tumors, has dramatically changed the treatment landscape of NSCLC.

In the 1970s, baseline performance status, extent of disease, and weight loss represented the main predictors of survival [3]. With deep understanding of genomic landscape in cancer, treatment of NSCLC has faced the era of therapy based on tumor molecular characteristics. This new knowledge allowed the development and clinical introduction of personalized molecular targeted therapies [4].

Lung cancers usually evolve through a multistage process that can extend over a period of decades. This process is driven by the progressive accumulation of mutations and epigenetic abnormalities leading to the expression of multiple genes with different functions [5]. Despite this complexity, cancer cell growth and survival can often be impaired by the inactivation of a single oncogene [6]. Each somatic alteration occurring in a single cancer cell may be classified according to its consequences for cancer development. Driver mutations confer a growth advantage to the cells and have been positively selected during the cancer evolution. This phenomenon, called oncogene addiction, provides a rationale for molecular targeted therapy [6-8]. Numerous driver mutations have been identified in NSCLC, predominantly epidermal growth factor receptor (EGFR) and KRAS mutations, and EML4-ALK translocations [9]. Alterations involving ROS1, BRAF, MET, and NRTK genes are less frequent but featured by a strong targeting potential.

Nevertheless, the vast majority ( $97 \%$ ) of mutations occurring during oncogenesis are passengers. Passenger mutations have no direct effect in terms of selective growth advantage for cancer cells, but they may be associated with a clonal expansion when occurring concomitantly with a driver mutation [4]. These mutations are likely to have only minimal biological consequences on the disease process, but their potentiality and role remain poorly understood. Therefore, a cell that acquires a molecular driver has probably already passenger somatic mutations within its genome [10].

Oncogene-addicted disease has also been evaluated in terms of tumor mutational burden (TMB), an emerging candidate biomarker for immune checkpoint inhibitors efficacy in lung cancer. TMB is usually low in oncogene-addicted tumors and there is an inverse correlation between TMB and clinical benefit deriving from EGFR-TKIs as assessed by OS and time to treatment discontinuation (TTD) [11]. On the contrary, PD-L1 is generally high in EGFR-mutated NSCLC, but immunotherapy appeared to be less effective in this subgroup of patients, and treatment is often burdened by serious side effects (Tables 1 and 2); [12-23]. In addition, in contrast to non-oncogene addicted disease, oncogene-addicted disease has a low early resistance rate, but late acquired resistance always develops (Table 3).

In both cases, cancer represents a dynamic disease and over time it becomes more and more heterogeneous. As a result of this heterogeneity, a tumor may include different clones of tumor cells harboring distinct molecular signatures and with differential levels of treatment sensitivity [24]. Cancer molecular heterogeneity, in particular co-occurring genetic alterations, could also explain the variable response to TKIs observed in oncogene-addicted disease. Concomitant gene alterations collaboratively act as co-drivers favoring tumor progression and drug resistance. As an example, TP53 mutation is the most frequent genetic alteration co-occurring in EGFR-mutant NSCLC. This gene encodes a tumor suppressor protein that is involved in DNA repair, metabolism, cell cycle arrest, apoptosis, and senescence [25]. Non-disruptive TP53 mutations (those preserving some functional properties of the protein) represent an independent prognostic factor of shorter OS in advanced NSCLC (13.3 versus 24.6 months; $\mathrm{HR}=2.08 ; p<0.001$ ) [26]. Overall, the majority of recent studies have shown 
that TP53 mutations are associated with poorer OS in NSCLC patients and support the hypothesis that TP53 (and perhaps other tumor suppressor genes) may affect the efficacy of traditional targeted therapy in molecularly-addicted NSCLC patients by triggering cell proliferation and passing the oncogenic power of the EGFR pathway [27-29]. To summarize, both TP53 mutations and TMB may be considered predictors of TKIs efficacy in oncogene-addicted disease [11,27,29].

Table 1. Immunotherapy in oncogene-addicted disease.

\begin{tabular}{|c|c|c|c|c|c|c|}
\hline Study & Treatment & Patients & ORR, \% & $\mathrm{Gr}>3 \mathrm{AE}$ & $\begin{array}{l}\text { Median PFS, } \\
\text { Mos }\end{array}$ & $\begin{array}{c}\text { Median OS, } \\
\text { Mos }\end{array}$ \\
\hline $\begin{array}{l}\text { TATTON } \\
\text { Phase } \mathrm{Ib}\end{array}$ & $\begin{array}{l}\text { Osimertinib + } \\
\text { Durvalumab }\end{array}$ & $\begin{array}{l}\text { EGFR+ TKI } \\
\text { naïve }\end{array}$ & 70 & $\begin{array}{c}47 \%(15 \% \\
\text { pneumonitis) }\end{array}$ & $\begin{array}{c}\text { Not } \\
\text { applicable }\end{array}$ & $\begin{array}{c}\text { Not } \\
\text { applicable }\end{array}$ \\
\hline $\begin{array}{c}\text { NCT } 02088112 \\
\text { Phase I }\end{array}$ & $\begin{array}{c}\text { Gefitinib + } \\
\text { Durvalumab }\end{array}$ & $\begin{array}{c}\text { EGFR+ TKI } \\
\text { naïve }\end{array}$ & 79 & $50 \%$ Mainly liver & $\begin{array}{c}\text { Not } \\
\text { applicable }\end{array}$ & $\begin{array}{c}\text { Not } \\
\text { applicable }\end{array}$ \\
\hline $\begin{array}{c}\text { NCT } 02013219 \\
\text { Phase Ib }\end{array}$ & $\begin{array}{c}\text { Erlotinib + } \\
\text { Atezolizumab }\end{array}$ & EGFR+ & 75 & $\begin{array}{c}\text { 39\% Mainly } \\
\text { pyrexia and liver }\end{array}$ & $\begin{array}{c}\text { Not } \\
\text { applicable }\end{array}$ & $\begin{array}{c}\text { Not } \\
\text { applicable }\end{array}$ \\
\hline $\begin{array}{l}\text { GEFTREM } \\
\text { Phase I }\end{array}$ & $\begin{array}{c}\text { Gefitinib + } \\
\text { Tramelimumab }\end{array}$ & $\begin{array}{c}\text { EGFR+ PD } \\
\text { on TKI }\end{array}$ & $\begin{array}{c}67 \\
\text { stable disease }\end{array}$ & $\begin{array}{l}54 \% \text { Mainly } \\
\text { diarrhea }\end{array}$ & $\begin{array}{c}\text { Not } \\
\text { applicable }\end{array}$ & $\begin{array}{c}\text { Not } \\
\text { applicable }\end{array}$ \\
\hline $\begin{array}{l}\text { NCT } 01454102 \\
\text { Phase I }\end{array}$ & Elotinib + Nivolumab & EGFR+ & 19 & $\begin{array}{l}\text { 24\% Mainly liver } \\
\text { and diarrhea }\end{array}$ & $\begin{array}{c}\text { Not } \\
\text { applicable }\end{array}$ & $\begin{array}{c}\text { Not } \\
\text { applicable }\end{array}$ \\
\hline $\begin{array}{c}\text { Checkmate } 370 \\
\text { Phase } 1 / 2\end{array}$ & $\begin{array}{l}\text { Crizotinib + } \\
\text { Nivolumab }\end{array}$ & ALK+ & 38 & $\begin{array}{l}62 \% \text { Mainly } \\
\text { hepatitis and } \\
\text { pneumonitis }\end{array}$ & & \\
\hline $\begin{array}{c}\text { Nivolumab EAP } \\
\text { Phase I }\end{array}$ & Nivolumab & EGFR+/ALK+ & 9 & $7 \%$ & $3(2.7-3.3)$ & $8.3(2.2-14.4)$ \\
\hline $\begin{array}{c}\text { IMPOWER } 150 \\
\text { Phase } 3\end{array}$ & $\begin{array}{c}\text { Atezolizumab + } \\
\text { Carboplatin-Paclitaxel } \\
+ \text { Bevacizumab vs. } \\
\text { Bevacizumab + } \\
\text { Carboplatin - } \\
\text { Paclitaxel }\end{array}$ & $\begin{array}{l}\text { EGFR+/ALK+ } \\
\text { PD on TKI }\end{array}$ & 71 & $57 \%$ & 10.2 vs. 6.9 & NR vs. 18.7 \\
\hline
\end{tabular}

AE: adverse events; MoS: months.

Table 2. Subgroup analyses of epidermal growth factor receptor (EGFR+) and anaplastic lymphoma kinase $(\mathrm{ALK}+)$ patients in large randomized control trials with immune checkpoint inhibitors.

\begin{tabular}{cccc}
\hline Study & Treatment & Design & HR OS [95\% CI] \\
\hline $\begin{array}{c}\text { KEYNOTE 010 } \\
\text { Phase II/III }\end{array}$ & $\begin{array}{c}\text { Pembrolizumab } \\
\text { Docetaxel }\end{array}$ & PDL1+ NSCLC & $0.88(0.45-1.70)$ \\
\hline $\begin{array}{c}\text { POPLAR } \\
\text { Phase II }\end{array}$ & $\begin{array}{c}\text { Atezolizumab } \\
\text { Docetaxel }\end{array}$ & NSCLC & $0.99(0.29-3.40)$ \\
\hline $\begin{array}{c}\text { Checkmate 057 } \\
\text { Phase III }\end{array}$ & $\begin{array}{c}\text { Nivolumab } \\
\text { Docetaxel }\end{array}$ & Non-squamous NSCLC & $1.18(0.69-2.00)$ \\
\hline $\begin{array}{c}\text { OAK } \\
\text { Phase III }\end{array}$ & $\begin{array}{c}\text { Atezolizumab } \\
\text { Docetaxel }\end{array}$ & NSCLC & $1.24(0.71-2.18)$ \\
\hline
\end{tabular}

Table 3. Differences between oncogene-addicted and non-oncogene addicted disease.

\begin{tabular}{ccc}
\hline Characteristics & Oncogene Addicted Disease & Non-Oncogene Addicted Disease \\
\hline Number of Drivers & Single (Dominant) Driver & Multiple Drivers and Passengers \\
\hline $\begin{array}{c}\text { Mutational Load } \\
\text { Tumor Mutational Burden (TMB) }\end{array}$ & Small \\
LOW TMB & HIGH TMB \\
\hline Efficacy of Targeted Therapy (TKIs) & Yes, proven & No, still unproven \\
\hline Efficacy of Immunotherapy & No, still unproven & Yes, proven \\
\hline Early Resistance Rate & Low ( $\leq 20 \%$ at first evaluation) & High ( $\geq 50 \%$ at first evaluation) \\
\hline $\begin{array}{c}\text { Late Acquired Resistance (same/other pathways) } \\
\text { Traditional Intermediate End-points Surrogacy } \\
\text { (in absence of cross-over) }\end{array}$ & Always, proven & $\begin{array}{c}\text { Few Late Acquired Resistance, } \\
\text { unproven (long survivors, } \\
\text { cured patients?) }\end{array}$ \\
\hline
\end{tabular}




\section{EGFR Mutations}

Mutations in EGFR (either small in-frame deletions in exon 19, del19, or amino acid substitution (leucine to arginine at codon 858, L858R) clustered around the ATP-binding pocket of the tyrosine kinase domain) are present in 10-26\% of NSCLC and are more frequent in the Asiatic population [30]. Studies on lung cancer cell lines and transgenic mice harboring EGFR mutations have shown the oncogenic potential of these mutations, with enhanced response to EGFR inhibitors [31].

Since 2005, some clinical trials evaluated the efficacy of EGFR inhibitors in patients experiencing progressive disease after chemotherapy, regardless of their mutational profile, suggesting a modest advantage versus placebo $[32,33]$. In the same period, first data demonstrated that a subgroup of patients with NSCLC has specific mutations in the EGFR gene, which correlate with clinical responsiveness to the tyrosine kinase inhibitor gefitinib [34]. Mok et al. compared head-to-head gefitinib versus carboplatin-paclitaxel in patients with untreated lung adenocarcinoma, non-smokers or ex-smokers, demonstrating an increase in progression-free survival (PFS) in patients treated with gefitinib, with the greater benefit in the subgroup of patients who were positive for EGFR mutation [35].

The mechanism of action of first-generation EGFR-TKIs (as gefitinib and erlotinib) is to reversibly block the activation of downstream signaling induced by EGFR through binding to the ATP-binding sites.

In 2009 gefitinib was the first EGFR TKI approved as first-line treatment of advanced NSCLC patients harboring activating EGFR mutations, as demonstrated in four major clinical trials. The Iressa Pan-Asia Study (IPASS) trial [36] was the first randomized clinical trial to compare EGFR-TKI with chemotherapy in patients affected by lung adenocarcinoma who were former light smokers or nonsmokers. A significant benefit in terms of PFS was reported in favor of gefitinib, while no difference in OS was found between both treatments groups [18.8 versus 17.4 months, HR 0.90; 95\% confidence intervals (CI) $0.79-1.02 ; p<0.109$ ], although this result was likely confounded by the high proportion of patients in the control arm who received TKI as subsequent treatment. Interestingly, the PFS benefit was confirmed only in the EGFR mutation-positive subgroup (median PFS 9.5 versus 6.3 months, HR 0.48 [95\% CI 0.36-0.64]; $p<0.001$ ), while in the EGFR mutation-negative subgroup TKI was inferior to chemotherapy (median PFS 1.5 versus 5.5 months, HR 2.85 [95\% CI 2.05-3.98]; $p<0.001$ ). Thus, activating EGFR mutations were identified as a relevant predictive factor for response to gefitinib. The outcomes of the other three trials (First-SIGNAL, NEJ002, and WJTOG3405) [37-39] confirmed the IPASS results in EGFR-mutant NSCLC patients when comparing gefitinib with doublet chemotherapy as first-line therapy. In all these studies, rash and liver dysfunction were the most common adverse events (AEs) reported with grade 3-4 toxicities described in less than 30\% of patients [37].

Erlotinib received approval as a first-line treatment for patients with EGFR mutation in 2011 EURTAC [40] and OPTIMAL trials [41,42] proved the superiority in terms of PFS of erlotinib over first-line platinum-based chemotherapy in NSCLC patients harboring EGFR mutation (13.1 versus 4.6 months; HR 0.16 [95\% CI 0.10-0.26]; $p<0.0001$ ). Skin rash and liver dysfunction were described as the most common AEs with a low rate of grade $3-4$ toxicities (17\%) [41].

Novel EGFR TKIs were developed in order to improve the outcome of EGFR-mutated NSCLC. In 2013 the Food and Drug Administration (FDA) and the European Medicines Agency (EMA) approved afatinib in first-line treatment of EGFR mutant patients. Afatinib is a second-generation, orally bioavailable, irreversible EGFR inhibitor that can modify conserved cysteine residues within the catalytic domains of EGFR, HER2, and ErbB-4. By an irreversible covalent bond, it blocks enzymatic activity of active ErbB receptor family members until the synthesis of new receptors, thus the inhibitory action of afatinib is longer than reversible EGFR TKIs [43]. LUX-lung 3 and LUX-lung 6 trials [44,45] were randomized studies that compared afatinib with cisplatin plus pemetrexed or cisplatin plus gemcitabine as first-line treatment in patients affected by lung adenocarcinoma harboring EGFR mutations. Afatinib significantly improved PFS and overall response rate (ORR) compared with chemotherapy. A retrospective pooled analysis of LUX-lung 3 and LUX-lung 6 demonstrated an OS benefit with afatinib only in the del19 group and not in the L858R mutation group, suggesting 
an intrinsic prognostic meaning of these two mutations [46]. In LUX-lung 3 and LUX-lung 6 trials, the overall frequency of patients with uncommon EGFR mutations was $11 \%$ and afatinib showed activity for the majority of them. Based on these results, in 2018 the FDA approved afatinib for uncommon EGFR mutant patients. The most common treatment-related AEs reported were diarrhea, rash/acne, stomatitis, and nail effects; AEs grade 3-4 occurred in $49 \%$ of patients [44].

Dacomitinib is a pan-HER TKI, able to target EGFR, ErbB2, and ErbB4 kinase, and it regulates the EGFR signaling pathway by irreversibly bind to the ATP-pocket [47,48]. In the ARCHER 1050 trial, dacomitinib significantly improves PFS and OS compared with gefitinib (34.1 versus 26.8 months, HR 0.76; $p=0.044$ ). Although the ARCHER 1050 trial was conducted in the Asiatic population without brain metastases, dacomitinib is the only TKI that has shown superior OS in comparison with another TKI. This benefit was achieved at the cost of higher toxicity, especially dermatitis acneiform, diarrhea, and liver dysfunction (frequency of grade 3-4 adverse events $63 \%$ versus $41 \%$ ) and a detrimental effect on quality of life (QoL) [49]. Based on ARCHER 1050 results, in 2019 the EMA approved dacomitinib in patients with EGFR del19 or 21L858R.

Multiple phase III trials comparing first- and second-generation EGFR TKIs with platinum-based chemotherapy as frontline treatment for patients affected by advanced NSCLC have been reported. A consistent benefit in favor of EGFR TKIs was observed across all studies in terms of PFS, ORR, and disease control rate. The median PFS with these compounds ranged from 8.0-13.1 months, compared with 4.6-6.9 months with chemotherapy [50].

With the exception of ARCHER 1050 trial with dacomitinib, in comparative studies, no relevant differences in terms of efficacy were observed between the other first- and second-generation EGFR TKIs. In CTONG 0901 [51] trial, patients were randomized to receive erlotinib or gefitinib. Median OS was similar (22.9 versus 20.1 months [95\% CI 0.63-1.13], $p=0.250$ ). In LUX-Lung 7 [52] trial, patients were randomized to receive afatinib or gefitinib. A median OS of 27.9 versus 24.5 months $(H R=0.86$, $95 \%$ CI 0.66-1.12; $p=0.2580$ ) was reported, while PFS was significantly improved with afatinib (HR = $0.73,95 \%$ CI $0.57-0.95 ; p=0.0165$ ) although with a greater toxicity (grade $\geq 3$ adverse events $31.3 \%$ versus $19.5 \%)$.

To sum up, in the pre-osimertinib era, in the treatment of lung cancer patients with common EGFR mutations (L858R and exon del19), the choice of a first or second-generation EGFR TKI depends on toxicity profile, physician's preference, and the local availability of each agent. With regard to metabolism, afatinib is not an inhibitor or an inducer of CYP450 enzymes. Therefore, in patients who need concomitant medications, afatinib therapy reduces the risk of drug-drug interactions.

Despite high initial response and disease control rate, virtually all patients receiving these EGFR TKIs eventually experience tumor progression due to the emergence of drug resistance [53]. Resistance to TKIs is most commonly acquired de novo during treatment, but can also occur due to the outgrowth of pre-existing resistant subclones [24]. In approximately 50\% of patients treated with first- and second-generation EGFR TKIs, resistance is mediated by the acquisition of the gatekeeper T790M mutation, which results in the sterical blockade of these TKIs binding and concurrently increases the kinase affinity for ATP [54]. T790M often coexisted with pre-existing sensitizing EGFR mutations, such as del19 or 21L858R, in particular with 21L858R rather than del19 [55].

In order to increase the awaited benefit in EGFR-mutant NSCLC patients, new TKIs were developed. Among them, osimertinib is an irreversible third-generation EGFR TKI that is active against T790M resistance mutation other than del19 and L858R sensitizing mutations. This TKI forms a covalent bond to the cysteine residue at position 797 and has lower activity than the aforementioned TKIs against wild-type EGFR protein, therefore improving its safety profile.

In the AURA 3 randomized phase III trial [56], osimertinib significantly prolonged median PFS and ORRs than cisplatin plus pemetrexed in T790M positive NSCLC patients who had disease progression after first-line EGFR-TKI. In comparison with chemotherapy, patients receiving osimertinib had also a lower incidence of grade $\geq 3$ adverse events ( $23 \%$ vs. $47 \%$ ) and an improved QoL with better scores for lung cancer symptoms [56]. The extended benefit of the sequential administration of a 
first-generation EGFR TKI followed by osimertinib observed in this study led to the approval of this compound for patients with NSCLC harboring T790M mutation and experiencing disease progression after first-generation or second-generation EGFR TKIs. In this setting, blood-based and/or tumor sampling analysis is mandatory to determine the T790M mutational status after disease progression, owing to the clinical benefits that may be obtained from a sequential strategy with osimertinib [57-59]. Plasma circulating tumor-DNA (ctDNA) still cannot fully replace tissue to diagnose acquired T790M mutation after disease progression due to a lower sensitivity of the blood analysis [60]. Given the reduced risk of plasma analysis compared with an invasive biopsy procedure, data support a new paradigm for resistance management, with rapid plasma genotyping as a diagnostic option before undergoing a tumor biopsy. Patients negative for T790M in plasma, however, should undergo a biopsy to determine T790M status because of the risks of false-negative plasma results [61].

Wang et al., collected clinical characteristics of patients diagnosed with EGFR mutation and identified patients with primary and acquired T790M mutation. They found that primary T790M mutation appears to be basically refractory to older TKI. Conversely, osimertinib works with the same impact in patients with primary or acquired T790M [55]. Based on this evidence [62,63], it was suggested that osimertinib may also be an effective first-line therapy for patients with advanced EGFR mutated NSCLC. In the phase 3 FLAURA trial, osimertinib significantly improved PFS compared with standard EGFR-TKIs gefitinib and erlotinib as first-line treatment of EGFR mutated advanced NSCLC, with a similar safety profile and lower rate of serious adverse events [64]. Due to greater penetration of the BBB, osimertinib also reduced CNS progression events [64]. Furthermore, TTD and time to second progression were superior in osimertinib-treated patients and more patients received further lines of therapy [65]. The final OS analysis has shown that osimertinib improves OS in comparison with standard of care (median OS 38.6 [95\% CI 34.5-41.8] versus 31.8 months [95\% CI 26.6-36]; HR 0.799, $p=0.046)$ [66]. Comparing the recent randomized clinical trials with the FLAURA control arm, first- and second-generation TKIs show an inferior median OS in comparison with the osimertinib arm. Moreover, $30 \%$ of patients do not receive subsequent anti-cancer treatment both after first-line osimertinib and standard of care TKIs [64]. This evidence suggests that the best treatment should be used in the first-line setting, avoiding that proportion of patients that will not be treated with a second-line therapy. On the basis of all these data, osimertinib is highly recommended in the first-line setting of EGFR mutant advanced NSCLC thanks to its superiority in terms of PFS, OS, and intracranial efficacy with a manageable toxicity profile. Few data are available for uncommon EGFR mutations, but results are consistent with previous reports confirming osimertinib efficacy [67].

In AURA 3 and FLAURA trials mechanisms of resistance to osimertinib have been identified through plasma samples collected at baseline and following disease progression. The most common acquired resistance mechanism detected were MET amplification and EGFR C797S mutation (about $15 \%$ each); other mechanisms included HER2 amplification, PIK3CA, KRAS, NRTK, RET, and FGFR3 mutations (2-7\%) [68] (Table 4).

To better control disease progression and improve clinical outcomes, many studies have evaluated the combination of TKI with other drugs. In a TATTON study, a phase Ib trial, MET-amplified, and EGFR-mutant patients were treated with osimertinib plus savolitinib showing an acceptable risk-benefit profile and encouraging anti-tumor activity of the combination (objective partial responses in $48 \%$ of patients) [69]. In a RELAY trial, patients were randomly assigned to receive erlotinib plus ramucirumab or erlotinib plus placebo showing that PSF was significantly longer in the ramucirumab plus erlotinib group (19.4 months (95\% CI 15.4-21.6)) than in the placebo plus erlotinib group (12.4 months (95\% CI 11.0-13.5)), with HR $=0.59$ (95\% CI 0.46-0.76; $p<0.0001$ ). Grade 3-4 treatment-emergent adverse events were reported in $72 \%$ in the ramucirumab plus erlotinib group versus $54 \%$ in the placebo plus erlotinib group [70]. Many trials have evaluated the combination of erlotinib plus bevacizumab versus erlotinib plus placebo but, to date, there is no evidence of OS benefit (Table 4). Norohna et al. have demonstrated that a combination of gefitinib plus pemetrexed/carboplatin significantly prolonged PFS and OS but increased toxicity in EGFR-mutant patients with advanced NSCLC [71]. 
Table 4. Phase 3 comparative studies in the targeted therapy of EGFR mutant non-small-cell lung cancer (NSCLC).

\begin{tabular}{|c|c|c|c|c|c|}
\hline Study & $\mathbf{N}$ & Treatment & ORR, \% & Median PFS, Mos & Median OS, Mos \\
\hline IPASS & 261 & $\begin{array}{c}\text { Gefitinib vs. } \\
\text { carboplatin/paclitaxel }\end{array}$ & 71 vs. 47 & $\begin{array}{l}9.8 \text { vs. } 6.4 \\
(p<0.001)\end{array}$ & 21.6 vs. 21.9 (HR: 1.00$)$ \\
\hline FIRST-SIGNAL & 42 & $\begin{array}{c}\text { Gefitinib vs. } \\
\text { cisplatin/gemcitabine }\end{array}$ & 84 vs. 37 & $\begin{array}{l}8.4 \text { vs. } 6.7 \\
(p<0.084)\end{array}$ & 27.2 vs. 25.6 (HR: 1.04$)$ \\
\hline NEJ002 & 230 & $\begin{array}{c}\text { Gefitinib vs. } \\
\text { carboplatin/paclitaxel }\end{array}$ & 74 vs. 31 & $\begin{array}{l}10.8 \text { vs. } 5.4 \\
(p<0.001)\end{array}$ & 30.5 vs. 23.6 (HR: 0.89$)$ \\
\hline WJTOG 3405 & 172 & $\begin{array}{c}\text { Gefitinib vs. } \\
\text { cisplatin/docetaxel }\end{array}$ & 62 vs. 32 & $\begin{array}{l}9.6 \text { vs. } 6.6 \\
(p<0.001)\end{array}$ & 34.8 vs. 37.3 (HR: 1.25$)$ \\
\hline OPTIMAL & 165 & $\begin{array}{c}\text { Erlotinib vs. } \\
\text { carboplatin/gemcitabine }\end{array}$ & 83 vs. 36 & $\begin{array}{l}13.1 \text { vs. } 4.6 \\
(p<0.0001)\end{array}$ & 22.8 vs. 27.2 (HR: 1.19$)$ \\
\hline EURTAC & 174 & $\begin{array}{l}\text { Erlotinib vs. } \\
\text { platinum-based } \\
\text { chemotherapy }\end{array}$ & 58 vs. 15 & $\begin{array}{c}9.7 \text { vs. } 5.2 \\
(p<0.0001)\end{array}$ & 22.9 vs. 19.5 (HR: 0.93 ) \\
\hline LUX-Lung 3 & 345 & $\begin{array}{c}\text { Afatinib vs. } \\
\text { cisplatin/pemetrexed }\end{array}$ & 56 vs. 23 & $\begin{array}{l}11.1 \text { vs. } 6.9 \\
(p=0.001)\end{array}$ & 28.2 vs. 28.2 (HR: 0.88 ) \\
\hline LUX-Lung 6 & 364 & $\begin{array}{c}\text { Afatinib vs. } \\
\text { cisplatin/gemcitabine }\end{array}$ & 67 vs. 23 & $\begin{array}{l}11.0 \text { vs. } 5.6 \\
(p<0.0001)\end{array}$ & 23.1 vs. 23.5 (HR: 0.93 ) \\
\hline LUX-Lung 7 & 319 & Afatinib vs. Gefitinib & 70 vs. 56 & $\begin{array}{l}11 \text { vs. } 10.9 \\
(p=0.0073)\end{array}$ & 27.9 vs. 24.5 (HR: 0.86 ) \\
\hline FLAURA & 556 & Osimertinib vs. Gefitinib & 80 vs. 76 & $\begin{array}{c}18.9 \text { vs. } 10.2 \\
(p<0.001)\end{array}$ & 38.6 vs. 31.8 (HR: 0.80 ) \\
\hline ARCHER & 452 & $\begin{array}{c}\text { Dacomitinib vs. } \\
\text { Gefitinib/Erlotinib }\end{array}$ & 74 vs. 71 & $\begin{array}{l}14.7 \text { vs. } 9.2 \\
(p<0.0001)\end{array}$ & 34.1 vs. 26.8 (HR: 0.76 ) \\
\hline NEJ 026 & 226 & $\begin{array}{c}\text { Erlotinib + Bevacizumab } \\
\text { vs. Erlotinib }\end{array}$ & 72 vs. 60 & $\begin{array}{l}16.9 \text { vs. } 13.3 \\
(p=0.0157)\end{array}$ & Not mature \\
\hline JO25567 & 152 & $\begin{array}{c}\text { Erlotinib + Bevacizumab } \\
\text { vs. Erlotinib }\end{array}$ & 69 vs. 64 & $\begin{array}{l}16 \text { vs. } 9.7 \\
(p=0.0015)\end{array}$ & 47.4 vs. 47 (HR: 0.81 ) \\
\hline Cheng JCO & 191 & $\begin{array}{l}\text { Gefitinib + Pemetrexed } \\
\text { vs. Gefitinib }\end{array}$ & 80 vs. 74 & $\begin{array}{c}15.8 \text { vs. } 10.9 \\
(p=0.029)\end{array}$ & 43.4 vs. 36.7 (HR: 0.77 ) \\
\hline NEJ009 & 344 & $\begin{array}{c}\text { Gefitinib + } \\
\text { Pemetrexed-Carboplatin } \\
\text { vs. Gefitinib }\end{array}$ & 84 vs. 67 & $\begin{array}{c}20.9 \text { vs. } 11.2 \\
(p<0.001)\end{array}$ & 52.2 vs. 38.8 (HR: 0.69$)$ \\
\hline RELAY & 449 & $\begin{array}{l}\text { Erlotinib }+ \\
\text { Ramucirumab vs. } \\
\text { Erlotinib }\end{array}$ & 76 vs. 75 & $\begin{array}{l}19.4 \text { vs. } 12.4 \\
(p<0.0001)\end{array}$ & Not mature \\
\hline $\begin{array}{l}\text { Norohna et al. } \\
\text { ASCO } 2019\end{array}$ & 350 & $\begin{array}{c}\text { Gefitinib + } \\
\text { Carboplatin/Pemetrexed } \\
\text { vs. Gefinitib }\end{array}$ & 75 vs. 62 & $\begin{array}{c}16 \text { vs. } 8 \\
(p<0.0001)\end{array}$ & NR vs. 17 (HR: 0.45) \\
\hline ARTEMIS & 311 & $\begin{array}{c}\text { Erlotinib + Bevacizumab } \\
\text { vs. Erlotinib }\end{array}$ & 157 vs. 154 & $\begin{array}{l}18 \text { vs. } 11.2 \\
(p<0.001)\end{array}$ & Not mature \\
\hline
\end{tabular}

Nowadays, it is clear that many efforts and steps forward have been made to improve clinical outcomes without worsening quality in this subgroup of patients, but there is still a long way to go.

\section{ALK Translocations}

Rearrangements of the anaplastic lymphoma kinase (ALK) gene are present in 3\% to $5 \%$ of NSCLC [72] and typically occur in younger patients who have never smoked or have a history of light smoking and that have adenocarcinoma histotype [73].

The identification of ALK translocation in NSCLC was reported for the first time in 2007, when in some preclinical models it was demonstrated that the chemical inhibition of ALK fusion protein led to a dramatic reduction in tumor cell growth and to a significant survival advantage of ALK-positive lung cancer murine xenografts [72]. The most frequent ALK translocations usually involve the gene coding for the Echinoderm Microtubule-associated protein Like 4 (EML4) [74,75]. After dimerization, EML4-ALK transcript constitutively triggers Mitogen-Activated Protein Kinase (MAPK), Janus Kinase 
with Signal Transducer And Activator Of Transcription (JAK-STAT) and Phosphoinositide-3-Kinase with VAkt Murine Thymoma Viral Oncogene Homolog (PI3K-AKT), leading to an increase in proliferation and survival and boosting the angiogenetic switch in cancer cells [76,77].

Besides EGFR, the discovery of ALK as a druggable oncogenic pathway in NSCLC led to the identification of an additional oncogene-addicted subgroup of NSCLC, for which the administration of ALK inhibitors completely changed the natural course of the disease.

Crizotinib is the pivotal ALK inhibitor that also inhibits ROS1 and MET receptor tyrosine kinases [78]. In the PROFILE 1001 [78] and PROFILE 1005 [79] phase I-II trials, crizotinib demonstrated good tolerability and showed an ORR of 59.8\% (95\% CI 53.6-65.9), a median PFS of 8.1 months (95\% CI 6.8-9.7), and a median duration of response of 10.5 months. The PROFILE 1007 trial is the first phase III trial comparing crizotinib to standard second-line chemotherapy (docetaxel or pemetrexed), in patients with advanced $A L K$-rearranged NSCLC, progressing after a first-line platinum-based chemotherapy. The median PFS was significantly longer for crizotinib compared to chemotherapy (7.7 versus 3 months, HR $0.49 ; 95 \%$ CI 0.37 to $0.64 ; p<0.0001)$ and ORR was strikingly in favor of crizotinib (65\% vs. 20\%; $p<0.001)$. The PROFILE 1014 trial compared crizotinib versus platinum-pemetrexed doublet in first-line setting and crizotinib still provided a significant improvement in PFS (10.9 vs. 7.4 months, HR 0.49, 95\% CI 0.36 to $0.67 ; p<0.0001)$. Both in the PROFILE 1007 and PROFILE $1014[80,81]$, the OS analysis showed no significant improvement with crizotinib as compared with chemotherapy (in the PROFILE 1007 HR $=0.82,95 \%$ CI 0.54-1.26, $p=0.36$; in the PROFILE 1014 HR = 1.02, 95\% CI 0.68-1.54, $p=0.54$ ), but this result was inevitably affected by the crossover rate (70\% of patients in chemotherapy arm). However, the adjusted HR for death ranged between 0.60 and 0.67 in favor of crizotinib. In consideration of the delay disease progression, upfront ALK TKIs therapy was approved in first-line [82].

Nevertheless, although the initial significant benefit, the efficacy of crizotinib, similarly to what happens with EGFR TKI in EGFR-mutant NSCLC, decreases after the onset of acquired resistance mechanisms, mainly secondary mutations in the ALK gene and activation of bypass tracks. Several innovative ALK inhibitors have recently demonstrated outstanding activity in both crizotinib-naïve and resistant ALK-rearranged NSCLC, with superior penetration of the BBB and RR on brain metastases.

Ceritinib is a second-generation, ATP competitive, highly selective ALK inhibitor, 20 times more potent than crizotinib against ALK protein kinases. Ceritinib is active against many ALK mutations that confer resistance to crizotinib, including C1156Y, F1174C, G1202R, and the gatekeeper mutation L1196M associated with high-level resistance to crizotinib. The ASCEND-4 and ASCEND-5 trials [82,83] demonstrated a statistically significant and clinically meaningful improvement in terms of PFS in favor of ceritinib versus chemotherapy respectively in TKI-naïve and in crizotinib pre-treated patients with advanced ALK-rearranged NSCLC. Nevertheless, in the alectinib era, few data are available regarding ceritinib post-alectinib with limited activity [84].

The current treatment algorithm radically changed with the introduction of alectinib, a potent, highly selective, second-generation ALK inhibitor which also showed high activity against L1196M, a common gatekeeper mutation leading resistance to crizotinib. The ALUR trial compared alectinib versus standard chemotherapy in advanced ALK positive NSCLC patients who have progressed on crizotinib. This trial demonstrated that PFS was significantly longer with alectinib (9.6 months [95\% CI 6.9-12.2] versus 1.4 months [95\% CI 1.3-1.6] with chemotherapy; HR 0.15) and also CNS ORR was significantly higher with alectinib $(54.2 \%)$ versus chemotherapy $(0 \% ; p<0.001)$ [85]. ALESIA, J-ALEX, and ALEX phase 3 trials [86-88] compared alectinib versus crizotinib as first-line treatment for ALK-rearranged disease in Asiatic (ALESIA and J-ALEX) and in worldwide (ALEX) population. In both trials, alectinib showed superior efficacy and lower toxicity compared to crizotinib. In the J-ALEX trial, at the final PFS analysis, median PFS was 34.1 months (22.1-not estimated) with alectinib and 10.2 months (8.2-12.0) with crizotinib (HR 0.37; 95\% CI 0.26-0.52). In the ALEX trial, PFS was significantly improved with alectinib versus crizotinib [HR 0.47 (95\% CI, 0.34-0.65; $p<0.001$ ]. Median PFS was 34.8 months (95\% CI 17.7-not able to be estimated) with alectinib and 10.9 months (95\% CI 9.1-12.9) with crizotinib (HR 0.43, 95\% CI 0.32-0.58). OS data are still immature but alectinib appears 
to be superior. The most frequent adverse events in the alectinib group were anemia, diarrhea, nausea, liver dysfunction, myalgia, and edema. Given this advantage in terms of PFS, alectinib has been approved in the first-line in patients with ALK-positive NSCLC and became the current standard-of-care.

Brigatinib is another potent second-generation ALK inhibitor which showed a dual inhibition of ALK (including L1196M mutation conferring resistance to crizotinib) and EGFR T790M. The ALTA-1L trial [89] evaluated head-to-head the efficacy of brigatinib, as compared with crizotinib, in first-line in patients with advanced ALK-positive NSCLC. This trial showed that the rate of PFS was higher with brigatinib than with crizotinib (estimated 12-month PFS, 67\% [95\% CI 56-75] vs. 43\% [95\% CI 32-53]; HR 0.49 [95\% CI 0.33-0.74]; $p<0.001)$. The ORR was 71\% (95\% CI 62-78) with brigatinib and $60 \%(95 \%$ CI 51-68) with crizotinib; the rate of intracranial response among patients with measurable lesions was 78\% (95\% CI 52-94) and 29\% (95\% CI 11-52), respectively [89]. The most frequent adverse events related to brigatinib were diarrhea, increased creatine kinase level, nausea, cough, and hypertension [89]. Comparing ALTA-1L and ALEX results, brigatinib and alectinib appear to have similar PFS and intracranial efficacy. With regard to safety, alectinib is associated with fewer grade $\geq 3$ adverse events (41\% with alectinib versus $61 \%$ with brigatinib) $[88,89]$.

Lorlatinib is a novel, selective and potent ATP-competitive ALK and ROS1 inhibitor, with very high activity against EML4-ALK and all the recognized mutations driving resistance to crizotinib, ceritinib, and alectinib. In a phase I study, activity was seen in patients with ALK-positive NSCLC, most of whom had CNS metastases and progression after ALK-directed therapy [90]. In a multicohort phase II trial lorlatinib showed substantial overall and intracranial activity both in treatment-naïve patients and in those who had progressed on crizotinib, second-generation ALK tyrosine kinase inhibitors, or after up to three previous ALK tyrosine kinase inhibitors. Shaw et al. have demonstrated the lorlatinib antitumor activity against ALK G1202R/del, a mutation that confer resistance to both first- and second-generation ALK inhibitors [91]. In this study, lorlatinib was highly effective against ALK G1202R/del, with an ORR of 57\%, median duration of response of 7.0 months, and median PFS of 8.2 months [92]. Thus, lorlatinib could represent an effective treatment option for patients with ALK-positive NSCLC in first-line or subsequent therapy to overcome acquired resistance mutations [93].

Although these drugs have radically changed the prognosis of this setting of disease, clinical outcomes in these patients vary. The presence of various breakpoints in the context of EML4-gene causes the formation of different variants of translocated EML4-ALK fusion proteins. These variants may be associated with the development of ALK resistance mutations, particularly G1202R, and provide a molecular link between variant and clinical outcome. [91].

Gainor J et al. presented the first study to evaluate mechanisms of resistance across a spectrum of first- and second-generation ALK inhibitors. Consistent with earlier reports, they found that only a minority of ALK-positive patients ( 20\%) developed ALK resistance mutations on crizotinib. By contrast, ALK resistance mutations were present in over one-half of patients progressing on second-generation ALK inhibitors, likely reflecting the greater potency and selectivity of these agents compared to crizotinib. In parallel, they observed that the spectrum of ALK resistance mutations was different following progression on second-generation ALK inhibitors compared to crizotinib. Most notably, ALK G1202R, which was present in only $2 \%$ of crizotinib-resistant biopsies, emerged as the most common ALK resistance mutation after treatment with second-generation ALK inhibitors [94]. While ALK G1202R was a common shared resistance mutation in each second-generation ALK inhibitor cohort, it is noteworthy that the spectrum of other ALK resistance mutations appeared to differ across agents. For example, ALK F1174 mutations were observed in several post-ceritinib biopsy specimens $(4 / 24 ; 16.7 \%)$ but were otherwise absent from post-alectinib and post-brigatinib biopsies. Therefore, it will be important to incorporate repeat tissue or liquid biopsies into clinical trials of next-generation ALK inhibitors both before treatment and at progression. On a practical level, this work will also allow clinicians to personalize ALK-targeted strategies based upon the presence or absence of specific ALK resistance mutations, which may ultimately translate into improved patient outcomes [94] (Table 5). 
Table 5. Phase 3 comparative studies in the targeted therapy of ALK-rearranged NSCLC.

\begin{tabular}{|c|c|c|c|c|c|}
\hline Study & Therapy & Treatment & ORR, \% & Median PFS, Mos & Median OS, Mos \\
\hline PROFILE 1007 & Second-line & $\begin{array}{c}\text { Crizotinib vs. } \\
\text { pemetrexed/docetaxel }\end{array}$ & 65 vs. 20 & $\begin{array}{c}7.7 \text { vs. } 3 \\
(p<0.0001)\end{array}$ & $\begin{array}{l}20.3 \text { vs. } 22.8 \\
(\mathrm{HR}=1.02)\end{array}$ \\
\hline PROFILE 1014 & First-line & $\begin{array}{l}\text { Crizotinib vs. cisplatin } \\
\text { and pemetrexed }\end{array}$ & 74 vs. 45 & $\begin{array}{l}10.9 \text { vs. } 7.4 \\
(p<0.0001)\end{array}$ & NR vs. 47.5 \\
\hline PROFILE 1029 & First-line & $\begin{array}{l}\text { Crizotinib vs. } \\
\text { Cisplatin/Carboplatin } \\
\text { and Pemetrexed }\end{array}$ & 85 vs. 46 & $\begin{array}{l}11.1 \text { vs. } 6.8 \\
(p<0.001)\end{array}$ & $\begin{array}{l}28.9 \text { vs. } 27.7 \\
(\mathrm{HR}=0.89)\end{array}$ \\
\hline ASCEND-5 & Third-line & $\begin{array}{c}\text { Ceritinib vs. } \\
\text { pemetrexed/docetaxel }\end{array}$ & 49 vs. 7 & $\begin{array}{c}6.7 \text { vs. } 1.6 \\
(p<0.0001)\end{array}$ & $\begin{array}{c}18.1 \text { vs. } 20.1 \\
(\mathrm{HR}=1)\end{array}$ \\
\hline ASCEND-4 & First-line & $\begin{array}{c}\text { Ceritinib vs. } \\
\text { Cisplatin/Carboplatin }+ \\
\text { Pemetrexed }\end{array}$ & 72 vs. 27 & 13.5 vs. 6.7 & $\begin{array}{l}\text { NR vs. } 26.2 \\
(\mathrm{HR}=0.73)\end{array}$ \\
\hline ALUR & Second-line & $\begin{array}{c}\text { Alectinib vs. } \\
\text { docetaxel/pemetrexed }\end{array}$ & $\begin{array}{l}37 \text { vs. } 3(p<0.001) \\
\text { CNS ORR: } 54 \text { vs. } 0\end{array}$ & $\begin{array}{l}9.6 \text { vs. } 1.4 \\
(p<0.001)\end{array}$ & 12.6 vs. NR \\
\hline ALESIA & First-line & Alectinib vs. Crizotinib & $\begin{array}{l}91 \text { vs. } 77(p<0.0001) \\
\text { CNS ORR: } 73 \text { vs. } 22\end{array}$ & NR vs. 11.1 & Not mature \\
\hline ALEX & First-line & Alectinib vs. crizotinib & $\begin{array}{c}83 \text { vs. } 75(p=0.09) \\
\text { CNS ORR: } 86 \text { vs. } 71\end{array}$ & 34.8 vs. 10.9 & Not mature \\
\hline J-ALEX & First-line & Alectinib vs. crizotinib & 85 vs. 70 & 34.1 vs. 10.2 & Not mature \\
\hline ALTA-1L & First-line & Brigatinib vs. crizotinib & $\begin{array}{l}71 \text { vs. } 60 p=0.0678 \\
\text { CNS ORR: } 78 \text { vs. } 29\end{array}$ & NR vs. 9.8 & Not mature \\
\hline
\end{tabular}

CNS: central nervous system; NR: not reached.

There are many new trials coming out for ALK-rearranged NSCLC. One of the most attractive clinical trials currently recruiting is "The NCI-NRG ALK master protocol." In this study, patients who have progressed on an ALK inhibitor will have a tissue genomic biopsy. This biopsy will determine the next treatment, based on the exact mutations in the progressed tumor. If the results of this study are better than the current standard of care, genomic testing upon progression, and individualized medicine could become the standard of care for ALK lung cancer progression [95].

\section{ROS1 Rearrangements}

The ROS1 oncogene encodes an orphan receptor tyrosine kinase related to ALK, along with members of the insulin-receptor family. ROS1 proto-oncogene receptor tyrosine kinase is activated by chromosomal rearrangement in a variety of human cancers, including NSCLC (approximately $1 \%$ of patients), cholangiocarcinoma, gastric cancer, ovarian cancer, and glioblastoma multiforme. Rearrangement leads to fusion of a portion of ROS1 that includes the entire tyrosine kinase. The resulting ROS1 fusion kinases are constitutively activated and drive cellular transformation [96,97].

The kinase domains of ALK and ROS1 share 77\% amino acid identity within the ATP-binding sites. Crizotinib binds with high affinity to both ALK and ROS1, which is consistent with this homology. In the PROFILE 1001 trial, crizotinib showed marked antitumor activity in patients with advanced ROS1-rearranged NSCLC (ORR 72\%, with a disease control rate equal to $90 \%$ and a median PFS of 19.2 months). On the basis of these results, crizotinib is currently recommended in the first-line setting for patients with advanced ROS1-rearranged NSCLC [78]. In phase 1-2 trials, ceritinib and lorlatinib demonstrated efficacy in this setting of disease (ORR 62\% for both TKIs) with a great intracranial response rate (63\% and 54\%, respectively) and acceptable safety profile [98-100]. Entrectinib achieved high response rates (ORR 77\%; CI 95\% 64-88) and durable responses (median duration of response 24.6 months; $95 \%$ CI 11.4-34.8) in phase 1-2 trials, including in patients with brain metastases [101]. In the TRIDENT-1 trial, a phase 1-2 study, repotrectinib showed to be safe and active in patients with advanced ROS-1 NSCLC achieving ORR of $82 \%$ in TKI-naïve patients and 39\% in TKI-pretreated patients. Repotrectinib was the only ROS1 inhibitor to show a potential to overcome TKI resistance mutations, notably G2032R, which is the most common ROS1 resistance mutation after crizotinib treatment [102]. With regard to these studies, it could be assumed that repotrectinib could become the 
treatment of choice in ROS1-rearranged patients to overcome G2032R resistance mutation. A larger sample size is necessary to validate these results.

\section{BRAF Mutations}

BRAF is an RAF kinase which is downstream of RAS and signals via the MAPK pathway. Signaling through RAF/MEK/ERK is complex, dependent on RAF dimerization, and limited by feedback inhibition of RAS signal. BRAF mutations are present in approximately $2-4 \%$ of lung adenocarcinomas, and the most common mutation is V600E [103]. BRAF mutations and other oncogenic drivers (EFGR, RAS, and ALK rearrangements) seem to be mutually exclusive [104]. The clinical outcome in patients with B V600E mutations is associated with shorter OS and lower response rates to platinum-based chemotherapy than in patients with BRAF wild-type. Prospective drug phase II trials of single-agent BRAF inhibitors (vemurafenib or dabrafenib) in patients with metastatic NSCLC and BRAF V600E show response rates of 30-40\% and median PFS of 5-7 months [105,106]. Addition of the MEK inhibitor trametinib to dabrafenib in patients with BRAF V600E has shown an ORR of 63.2\% (95\% CI 49.3-75.6) in pretreated patients and 64\% (95\% CI 46-79) in naïve patients [107,108]. Given these results, the EMA and FDA have approved dabrafenib in combination with trametinib for the treatment of patients with BRAF V600 mutation-positive advanced or metastatic NSCLC.

\section{MET Alterations}

MET is a high-affinity proto-oncogene receptor tyrosine kinase that, upon activation, drives oncogenic pathways involved in cell proliferation, survival, and metastasis. Two major MET variants may play a role as drivers: Met exon 14 skipping and MET amplification. MET alterations leading to exon 14 skipping occur in $\sim 4 \%$ of lung carcinomas, resulting in MET activation and sensitivity to MET inhibitors. Crizotinib demonstrated high activity in patients with MET exon 14 alterations (ORR 39\% and median duration of response of 9.1 months) [96,109]. Capmatinib is a highly potent and selective MET inhibitor. In the GEOMETRY mono-1 trial, capmatinib has demonstrated a clinically meaningful ORR and a manageable toxicity profile in patients with METexon 14 skipping NSCLC, particularly in treatment-naïve patients where the ORR is $72 \%$ [110]. In preclinical study, capmatinib has also shown preclinical activity in combination with gefitinib in EGFR-mutant, MET-amplified/overexpressing models of acquired EGFR-TKI resistance. A phase Ib/II trial [111] showed that this combination could be a promising treatment for patients with EGFR-mutated, MET-dysregulated NSCLC, particularly MET-amplified disease (ORR of $47 \%$ in patients with a MET gene copy number $\geq 6$ ). Tepotinib is another MET inhibitor that has shown promising activity in MET exon 14 skipping NSCLC with a favorable safety profile [112]. Further studies are needed to confirm these results. To date, crizotinib should be the treatment of choice for MET exon 14 altered NSCLC.

\section{RET Mutations}

The RET gene encodes a receptor tyrosine kinase that signals through the RAS/MAPK, PI3K/AKT, and JAK/STAT signaling pathways upon binding of native ligands [113]. Oncogenic RET gene rearrangements were first discovered in papillary thyroid cancer, primarily among patients exposed to ionizing radiation treatment or environmental radiation. The first RET gene fusion to be detected in lung cancer involved the $3^{\prime}$-end of RET and the $5^{\prime}$-end of the kinesin family member $5 \mathrm{~B}$ gene (KIF5B). KIF5B-RET and its variants are the best characterized RET fusions in NSCLC, but at least 12 other fusion partners have been identified to date [114]. Similar to ROS1 fusions, the prevalence of RET rearrangements in NSCLC is approximately $1 \%$ and RET rearrangement-positive patients tend to be young and never smokers. While no RET-selective inhibitors are currently FDA approved, numerous multikinase inhibitors (vandetanib, lenvatinib, sunitinib) have been studied in patients with RET-rearranged lung cancer, but outcomes were modest when compared to the efficacy of TKIs targeting other NSCLC oncogenic drivers (median PFS is 2.3 months, and median OS is 6.8 months) [115]. Selpercatinib (LOXO-292) is a new highly selective RET inhibitor that has shown 
preclinical activity against a variety of RET fusions, as well as the RET V804M gatekeeper resistance mutation [116]. In the LIBRETTO-001 trial, LOXO-292 has shown marked antitumor activity in RET fusion-positive NSCLC, both in pretreated and treatment naïve patients ORR was $68 \%$ and CNS ORR was $91 \%$ in chemotherapy pretreated patients; ORR was $85 \%$ in treatment naïve patients. The safety profile was also favorable with a low discontinuation rate due to toxicity [117]. In the ARROW trial, patients with advanced RET fusion NSCLC were treated with BLU-667 achieving a high response rate (ORR 60\% (95\% CI 42-76) in chemo-pretreated patients) and great intracranial activity [118]. Targeting RET is not currently routinely recommended and recruitment into open trials is strongly encouraged.

\section{NRTK Rearrangements}

NTRK proteins play a vital role in the growth, differentiation, and apoptosis of neurons in the peripheral and central nervous stems. Chromosomal rearrangements of NTRK1 and NTRK 2 are known drivers of oncogenesis in several malignancies, including NSCLC, where the incidence is 3-4\% [119]. Larotrectinib (LOXO-101) is a highly selective pan-TRK inhibitor that provided the first evidence of clinical benefit from TRK inhibition. Its efficacy was recently reported in a cohort of 55 patients with a variety of NTRK fusion-positive cancers, including four NSCLC patients. The outcomes across all the malignancies were promising with an ORR of 75\% (median PFS had not yet been reached) [120]. Among the four NSCLC patients, three continued to have ongoing responses to the drug (ranging from 5.7 to 12 months), whereas one patient had stable disease [121]. These data highlight larotrectinib's potent antitumor activity in NTRK fusion-positive patients. These findings led the FDA to grant accelerated approval of the drug for patients with solid tumors harboring an NTRK fusion without a known resistance mutation, making this the first pan-cancer approval of a TKI. The second-generation TRK-selective inhibitor, LOXO-195, has been used in two patients with NTRK fusion-positive cancer (colon and infantile fibrosarcoma) that developed resistance to larotrectinib. Both patients derived clear clinical benefits from the therapy [122]. Entrectinib (RXDX-101) is a first-generation pan-TRK inhibitor that also has activity against ROS1 and ALK fusions. Recently, a pooled analysis of ALKA-372-001, STARTRK-1, and STARTRK-2 trials reported the efficacy of entrectinib in 54 patients with NTRK fusion-positive solid tumors, revealing an ORR of 57.4\%, median PFS of 11.2 months, and median OS of 20.9 months [123]. Based on these results, entrectinib and larotrectinib represent a rationale treatment choice in patients carrying NTRK rearrangements.

\section{HER2 Aberrations}

HER2 is a tyrosine kinase receptor of the ErbB/HER family and its amplification and overexpression represent a driver mutation in breast, ovarian, and gastric cancers [124]. HER2 aberration is found in $2-4 \%$ (mainly amplification and in-frame exon 20 insertions) of lung adenocarcinoma and it is one of the main mechanisms of acquired resistance to TKIs [125]. Targeted therapies such as dacomitinib, trastuzumab, and lapatinib have shown limited activity in NSCLC with HER2 alterations [126]. Afatinib and poziotinib have demonstrated some activity in HER2-mutated NSCLC [127,128]. Recently, two trastuzumab-based trials showed some promise for either the adotrastuzumab-emtansine conjugate (TDM-1) or trastuzumab/paclitaxel combination for HER2-positive lung cancers [129,130]. In vitro experiments have shown that osimertinib and pyrotinib have activity against NSCLC with HER2 exon 20 mutations [131,132].

To date, given the absence of robust data, targeting HER2 dysregulation is not currently recommended and there are no truly efficacy targeted therapies available. Therefore, recruitment into clinical trials is strongly recommended for these oncogene addicted diseases.

\section{Conclusions}

Undoubtedly, the advent of target therapy has radically changed the prognosis and the therapeutic paradigm of NSCLC patients. Within the last decade, much progress has been made in the identification of "driver" mutations and, consequently, of drugs that could delay tumor progression and markedly 
improve OS. Nevertheless, the percentage of patients with NSCLC carrying a driver mutation remains a minority. Certainly, further research is needed to identify further molecular targets and to develop new drugs to improve the prognosis and quality of life of these patients.

Author Contributions: Conception, E.B.; writing—original draft preparation, M.G.F., E.D., V.D.N., E.V., A.C., P.D., M.R.; writing-review and editing, S.P., M.M., E.B., and G.T. All authors have read and agreed to the published version of the manuscript.

Funding: This research received no external funding.

Acknowledgments: M.G.F., V.D.N, E.D., E.V., P.D., S.P., and E.B. are supported by the Italian Association for Cancer Research AIRC-IG 20583. E.B. is currently supported by Institutional funds of Università Cattolica del Sacro Cuore (UCSC-project D1-2018/2019).

Conflicts of Interest: E.B. received speaking and traveling fees from MSD, Astra-Zeneca, Celgene, Pfizer, Helsinn, Eli-Lilly, BMS, Novartis, and Roche. E.B. received consultant fees from Roche and Pfizer. E.B. received institutional research grants from Astra-Zeneca and Roche.

\section{References}

1. Siegel, R.L.; Miller, K.D.; Jemal, A. Cancer Statistics, 2017. CA Cancer J. Clin. 2017, 67, 7-30. [CrossRef] [PubMed]

2. Schiller, J.H.; Harrington, D.; Belani, C.P.; Langer, C.; Sandler, A.; Krook, J.; Zhu, J.; Johnson, D.H.; Eastern Cooperative Oncology, G. Comparison of four chemotherapy regimens for advanced non-small-cell lung cancer. New Engl. J. Med. 2002, 346, 92-98. [CrossRef] [PubMed]

3. Stanley, K.E. Prognostic factors for survival in patients with inoperable lung cancer. J. Natl. Cancer Inst. 1980, 65, 25-32. [PubMed]

4. Tan, C.S.; Gilligan, D.; Pacey, S. Treatment approaches for EGFR-inhibitor-resistant patients with non-small-cell lung cancer. Lancet Oncol. 2015, 16, e447-e459. [CrossRef]

5. Vogelstein, B.; Papadopoulos, N.; Velculescu, V.E.; Zhou, S.; Diaz, L.A., Jr.; Kinzler, K.W. Cancer genome landscapes. Science 2013, 339, 1546-1558. [CrossRef] [PubMed]

6. Weinstein, I.B.; Begemann, M.; Zhou, P.; Han, E.K.; Sgambato, A.; Doki, Y.; Arber, N.; Ciaparrone, M.; Yamamoto, H. Disorders in cell circuitry associated with multistage carcinogenesis: Exploitable targets for cancer prevention and therapy. Clin. Cancer Res. 1997, 3, 2696-2702.

7. Weinstein, I.B. Addiction to oncogenes-The Achilles heal of cancer. Science 2002, 297, 63-64. [CrossRef]

8. Weinstein, I.B.; Joe, A.K. Mechanisms of disease: Oncogene addiction-A rationale for molecular targeting in cancer therapy. Nat. Clin. Pract. Oncol. 2006, 3, 448-457. [CrossRef]

9. Barlesi, F.; Mazieres, J.; Merlio, J.P.; Debieuvre, D.; Mosser, J.; Lena, H.; Ouafik, L.; Besse, B.; Rouquette, I.; Westeel, V.; et al. Routine molecular profiling of patients with advanced non-small-cell lung cancer: Results of a 1-year nationwide programme of the French Cooperative Thoracic Intergroup (IFCT). Lancet 2016, 387, 1415-1426. [CrossRef]

10. Stratton, M.R.; Campbell, P.J.; Futreal, P.A. The cancer genome. Nature 2009, 458, 719-724. [CrossRef]

11. Offin, M.; Rizvi, H.; Tenet, M.; Ni, A.; Sanchez-Vega, F.; Li, B.T.; Drilon, A.; Kris, M.G.; Rudin, C.M.; Schultz, N.; et al. Tumor Mutation Burden and Efficacy of EGFR-Tyrosine Kinase Inhibitors in Patients with EGFR-Mutant Lung Cancers. Clin. Cancer Res. 2019, 25, 1063-1069. [CrossRef] [PubMed]

12. Oxnard, G.R.; Yang, J.C.; Yu, H.; Kim, S.W.; Saka, H.; Horn, L.; Goto, K.; Ohe, Y.; Mann, H.; Thress, K.S.; et al. TATTON: A multi-arm, phase $\mathrm{Ib}$ trial of osimertinib combined with selumetinib, savolitinib, or durvalumab in EGFR-mutant lung cancer. Ann. Oncol. 2020, 31, 507-516. [CrossRef]

13. Gibbons, D.L.; Chow, L.Q.; Kim, D.; Kim, S.W.; Yeh, T.; Song, X.; Jiang, H.; Taylor, R.; Karakunnel, J.; Creelan, B.; et al. 57O_Efficacy, safety and tolerability of MEDI4736 (durvalumab [D]), a human IgG1 anti-programmed cell death-ligand-1 (PD-L1) antibody, combined with gefitinib (G): A phase I expansion in TKI-naïve patients (pts) with EGFR mutant NSCLC. J. Thorac. Oncol. 2016, 11, S79. [CrossRef]

14. A Phase $1 \mathrm{~b}$ Study of Atezolizumab in Combination With Erlotinib or Alectinib in Participants With Non-Small Cell Lung Cancer (NSCLC). Available online: https://clinicaltrials.gov/ct2/show/NCT02013219 (accessed on 21 April 2020).

15. Tolerability and Efficacy of Tremelimumab in Combination With Gefitinib in NSCLC Patients (GEFTREM). Available online: https://clinicaltrials.gov/ct2/show/NCT02040064 (accessed on 21 April 2020). 
16. Study of Nivolumab (BMS-936558) in Combination With Gemcitabine/Cisplatin, Pemetrexed/Cisplatin, Carboplatin/Paclitaxel, Bevacizumab Maintenance, Erlotinib, Ipilimumab or as Monotherapy in Subjects With Stage IIIB/IV Non-small Cell Lung Cancer (NSCLC) (CheckMate 012). Available online: https: //clinicaltrials.gov/ct2/show/NCT01454102 (accessed on 5 March 2020).

17. Spigel, D.R.; Reynolds, C.; Waterhouse, D.; Garon, E.B.; Chandler, J.; Babu, S.; Thurmes, P.; Spira, A.; Jotte, R.; Zhu, J.; et al. Phase 1/2 Study of the Safety and Tolerability of Nivolumab Plus Crizotinib for the First-Line Treatment of Anaplastic Lymphoma Kinase Translocation-Positive Advanced Non-Small Cell Lung Cancer (CheckMate 370). J. Thorac. Oncol. 2018, 13, 682-688. [CrossRef] [PubMed]

18. Garassino, M.C.; Gelibter, A.J.; Grossi, F.; Chiari, R.; Soto Parra, H.; Cascinu, S.; Cognetti, F.; Turci, D.; Blasi, L.; Bengala, C.; et al. Italian Nivolumab Expanded Access Program in Nonsquamous Non-Small Cell Lung Cancer Patients: Results in Never-Smokers and EGFR-Mutant Patients. J. Thorac. Oncol. 2018, 13, 1146-1155. [CrossRef]

19. Reck, M.; Mok, T.S.K.; Nishio, M.; Jotte, R.M.; Cappuzzo, F.; Orlandi, F.; Stroyakovskiy, D.; Nogami, N.; Rodriguez-Abreu, D.; Moro-Sibilot, D.; et al. Atezolizumab plus bevacizumab and chemotherapy in non-small-cell lung cancer (IMpower150): Key subgroup analyses of patients with EGFR mutations or baseline liver metastases in a randomised, open-label phase 3 trial. Lancet Respir. Med. 2019, 7, 387-401. [CrossRef]

20. Herbst, R.S.; Baas, P.; Kim, D.W.; Felip, E.; Perez-Gracia, J.L.; Han, J.Y.; Molina, J.; Kim, J.H.; Arvis, C.D.; Ahn, M.J.; et al. Pembrolizumab versus docetaxel for previously treated, PD-L1-positive, advanced non-small-cell lung cancer (KEYNOTE-010): A randomised controlled trial. Lancet 2016, 387, 1540-1550. [CrossRef]

21. Fehrenbacher, L.; Spira, A.; Ballinger, M.; Kowanetz, M.; Vansteenkiste, J.; Mazieres, J.; Park, K.; Smith, D.; Artal-Cortes, A.; Lewanski, C.; et al. Atezolizumab versus docetaxel for patients with previously treated non-small-cell lung cancer (POPLAR): A multicentre, open-label, phase 2 randomised controlled trial. Lancet 2016, 387, 1837-1846. [CrossRef]

22. Borghaei, H.; Paz-Ares, L.; Horn, L.; Spigel, D.R.; Steins, M.; Ready, N.E.; Chow, L.Q.; Vokes, E.E.; Felip, E.; Holgado, E.; et al. Nivolumab versus Docetaxel in Advanced Nonsquamous Non-Small-Cell Lung Cancer. New Engl. J. Med. 2015, 373, 1627-1639. [CrossRef]

23. Rittmeyer, A.; Barlesi, F.; Waterkamp, D.; Park, K.; Ciardiello, F.; von Pawel, J.; Gadgeel, S.M.; Hida, T.; Kowalski, D.M.; Dols, M.C.; et al. Atezolizumab versus docetaxel in patients with previously treated non-small-cell lung cancer (OAK): A phase 3, open-label, multicentre randomised controlled trial. Lancet 2017, 389, 255-265. [CrossRef]

24. Dagogo-Jack, I.; Shaw, A.T. Tumour heterogeneity and resistance to cancer therapies. Nat. Rev. Clin. Oncol. 2018, 15, 81-94. [CrossRef] [PubMed]

25. Blakely, C.M.; Watkins, T.B.K.; Wu, W.; Gini, B.; Chabon, J.J.; McCoach, C.E.; McGranahan, N.; Wilson, G.A.; Birkbak, N.J.; Olivas, V.R.; et al. Evolution and clinical impact of co-occurring genetic alterations in advanced-stage EGFR-mutant lung cancers. Nat. Genet. 2017, 49, 1693-1704. [CrossRef] [PubMed]

26. Molina-Vila, M.A.; Bertran-Alamillo, J.; Gasco, A.; Mayo-de-las-Casas, C.; Sanchez-Ronco, M.; Pujantell-Pastor, L.; Bonanno, L.; Favaretto, A.G.; Cardona, A.F.; Vergnenegre, A.; et al. Nondisruptive p53 mutations are associated with shorter survival in patients with advanced non-small cell lung cancer. Clin. Cancer Res. 2014, 20, 4647-4659. [CrossRef] [PubMed]

27. Bria, E.; Pilotto, S.; Amato, E.; Fassan, M.; Novello, S.; Peretti, U.; Vavala, T.; Kinspergher, S.; Righi, L.; Santo, A.; et al. Molecular heterogeneity assessment by next-generation sequencing and response to gefitinib of EGFR mutant advanced lung adenocarcinoma. Oncotarget 2015, 6, 12783-12795. [CrossRef] [PubMed]

28. Canale, M.; Petracci, E.; Delmonte, A.; Chiadini, E.; Dazzi, C.; Papi, M.; Capelli, L.; Casanova, C.; De Luigi, N.; Mariotti, M.; et al. Impact of TP53 Mutations on Outcome in EGFR-Mutated Patients Treated with First-Line Tyrosine Kinase Inhibitors. Clin. Cancer Res. 2017, 23, 2195-2202. [CrossRef] [PubMed]

29. Aisner, D.L.; Sholl, L.M.; Berry, L.D.; Rossi, M.R.; Chen, H.; Fujimoto, J.; Moreira, A.L.; Ramalingam, S.S.; Villaruz, L.C.; Otterson, G.A.; et al. The Impact of Smoking and TP53 Mutations in Lung Adenocarcinoma Patients with Targetable Mutations-The Lung Cancer Mutation Consortium (LCMC2). Clin. Cancer Res. 2018, 24, 1038-1047. [CrossRef]

30. Pao, W.; Chmielecki, J. Rational, biologically based treatment of EGFR-mutant non-small-cell lung cancer. Nat. Rev. Cancer 2010, 10, 760-774. [CrossRef]

31. Ji, H.; Li, D.; Chen, L.; Shimamura, T.; Kobayashi, S.; McNamara, K.; Mahmood, U.; Mitchell, A.; Sun, Y.; Al-Hashem, R.; et al. The impact of human EGFR kinase domain mutations on lung tumorigenesis and in vivo sensitivity to EGFR-targeted therapies. Cancer Cell 2006, 9, 485-495. [CrossRef] 
32. Shepherd, F.A.; Rodrigues Pereira, J.; Ciuleanu, T.; Tan, E.H.; Hirsh, V.; Thongprasert, S.; Campos, D.; Maoleekoonpiroj, S.; Smylie, M.; Martins, R.; et al. Erlotinib in previously treated non-small-cell lung cancer. New Engl. J. Med. 2005, 353, 123-132. [CrossRef]

33. Thatcher, N.; Chang, A.; Parikh, P.; Rodrigues Pereira, J.; Ciuleanu, T.; von Pawel, J.; Thongprasert, S.; Tan, E.H.; Pemberton, K.; Archer, V.; et al. Gefitinib plus best supportive care in previously treated patients with refractory advanced non-small-cell lung cancer: Results from a randomised, placebo-controlled, multicentre study (Iressa Survival Evaluation in Lung Cancer). Lancet 2005, 366, 1527-1537. [CrossRef]

34. Lynch, T.J.; Bell, D.W.; Sordella, R.; Gurubhagavatula, S.; Okimoto, R.A.; Brannigan, B.W.; Harris, P.L.; Haserlat, S.M.; Supko, J.G.; Haluska, F.G.; et al. Activating mutations in the epidermal growth factor receptor underlying responsiveness of non-small-cell lung cancer to gefitinib. New Engl. J. Med. 2004, 350, 2129-2139. [CrossRef]

35. Mok, T.S.; Wu, Y.L.; Thongprasert, S.; Yang, C.H.; Chu, D.T.; Saijo, N.; Sunpaweravong, P.; Han, B.; Margono, B.; Ichinose, Y.; et al. Gefitinib or carboplatin-paclitaxel in pulmonary adenocarcinoma. New Engl. J. Med. 2009, 361, 947-957. [CrossRef] [PubMed]

36. Fukuoka, M.; Wu, Y.L.; Thongprasert, S.; Sunpaweravong, P.; Leong, S.S.; Sriuranpong, V.; Chao, T.Y.; Nakagawa, K.; Chu, D.T.; Saijo, N.; et al. Biomarker analyses and final overall survival results from a phase III, randomized, open-label, first-line study of gefitinib versus carboplatin/paclitaxel in clinically selected patients with advanced non-small-cell lung cancer in Asia (IPASS). J. Clin. Oncol. 2011, 29, 2866-2874. [CrossRef]

37. Han, J.Y.; Park, K.; Kim, S.W.; Lee, D.H.; Kim, H.Y.; Kim, H.T.; Ahn, M.J.; Yun, T.; Ahn, J.S.; Suh, C.; et al. First-SIGNAL: First-line single-agent iressa versus gemcitabine and cisplatin trial in never-smokers with adenocarcinoma of the lung. J. Clin. Oncol. 2012, 30, 1122-1128. [CrossRef] [PubMed]

38. Inoue, A.; Kobayashi, K.; Maemondo, M.; Sugawara, S.; Oizumi, S.; Isobe, H.; Gemma, A.; Harada, M.; Yoshizawa, H.; Kinoshita, I.; et al. Updated overall survival results from a randomized phase III trial comparing gefitinib with carboplatin-paclitaxel for chemo-naive non-small cell lung cancer with sensitive EGFR gene mutations (NEJ002). Ann. Oncol. 2013, 24, 54-59. [CrossRef]

39. Mitsudomi, T.; Morita, S.; Yatabe, Y.; Negoro, S.; Okamoto, I.; Tsurutani, J.; Seto, T.; Satouchi, M.; Tada, H.; Hirashima, T.; et al. Gefitinib versus cisplatin plus docetaxel in patients with non-small-cell lung cancer harbouring mutations of the epidermal growth factor receptor (WJTOG3405): An open label, randomised phase 3 trial. Lancet Oncol. 2010, 11, 121-128. [CrossRef]

40. Rosell, R.; Carcereny, E.; Gervais, R.; Vergnenegre, A.; Massuti, B.; Felip, E.; Palmero, R.; Garcia-Gomez, R.; Pallares, C.; Sanchez, J.M.; et al. Erlotinib versus standard chemotherapy as first-line treatment for European patients with advanced EGFR mutation-positive non-small-cell lung cancer (EURTAC): A multicentre, open-label, randomised phase 3 trial. Lancet Oncol. 2012, 13, 239-246. [CrossRef]

41. Zhou, C.; Wu, Y.L.; Chen, G.; Feng, J.; Liu, X.Q.; Wang, C.; Zhang, S.; Wang, J.; Zhou, S.; Ren, S.; et al. Erlotinib versus chemotherapy as first-line treatment for patients with advanced EGFR mutation-positive non-small-cell lung cancer (OPTIMAL, CTONG-0802): A multicentre, open-label, randomised, phase 3 study. Lancet Oncol. 2011, 12, 735-742. [CrossRef]

42. Chen, G.; Feng, J.; Zhou, C.; Wu, Y.L.; Liu, X.Q.; Wang, C.; Zhang, S.; Wang, J.; Zhou, S.; Ren, S.; et al. Quality of life (QoL) analyses from OPTIMAL (CTONG-0802), a phase III, randomised, open-label study of first-line erlotinib versus chemotherapy in patients with advanced EGFR mutation-positive non-small-cell lung cancer (NSCLC). Ann. Oncol. 2013, 24, 1615-1622. [CrossRef]

43. Jain, P.; Khanal, R.; Sharma, A.; Yan, F.; Sharma, N. Afatinib and lung cancer. Expert Rev. Anticancer. Ther. 2014, 14, 1391-1406. [CrossRef]

44. Sequist, L.V.; Yang, J.C.; Yamamoto, N.; O’Byrne, K.; Hirsh, V.; Mok, T.; Geater, S.L.; Orlov, S.; Tsai, C.M.; Boyer, M.; et al. Phase III study of afatinib or cisplatin plus pemetrexed in patients with metastatic lung adenocarcinoma with EGFR mutations. J. Clin. Oncol. 2013, 31, 3327-3334. [CrossRef] [PubMed]

45. Wu, Y.L.; Zhou, C.; Hu, C.P.; Feng, J.; Lu, S.; Huang, Y.; Li, W.; Hou, M.; Shi, J.H.; Lee, K.Y.; et al. Afatinib versus cisplatin plus gemcitabine for first-line treatment of Asian patients with advanced non-small-cell lung cancer harbouring EGFR mutations (LUX-Lung 6): An open-label, randomised phase 3 trial. Lancet Oncol. 2014, 15, 213-222. [CrossRef] 
46. Yang, J.C.; Wu, Y.L.; Schuler, M.; Sebastian, M.; Popat, S.; Yamamoto, N.; Zhou, C.; Hu, C.P.; O’Byrne, K.; Feng, J.; et al. Afatinib versus cisplatin-based chemotherapy for EGFR mutation-positive lung adenocarcinoma (LUX-Lung 3 and LUX-Lung 6): Analysis of overall survival data from two randomised, phase 3 trials. Lancet Oncol. 2015, 16, 141-151. [CrossRef]

47. Engelman, J.A.; Zejnullahu, K.; Gale, C.M.; Lifshits, E.; Gonzales, A.J.; Shimamura, T.; Zhao, F.; Vincent, P.W.; Naumov, G.N.; Bradner, J.E.; et al. PF00299804, an irreversible pan-ERBB inhibitor, is effective in lung cancer models with EGFR and ERBB2 mutations that are resistant to gefitinib. Cancer Res. 2007, 67, 11924-11932. [CrossRef] [PubMed]

48. Gonzales, A.J.; Hook, K.E.; Althaus, I.W.; Ellis, P.A.; Trachet, E.; Delaney, A.M.; Harvey, P.J.; Ellis, T.A.; Amato, D.M.; Nelson, J.M.; et al. Antitumor activity and pharmacokinetic properties of PF-00299804, a second-generation irreversible pan-erbB receptor tyrosine kinase inhibitor. Mol. Cancer Ther. 2008, 7, 1880-1889. [CrossRef] [PubMed]

49. Wu, Y.L.; Cheng, Y.; Zhou, X.; Lee, K.H.; Nakagawa, K.; Niho, S.; Tsuji, F.; Linke, R.; Rosell, R.; Corral, J.; et al. Dacomitinib versus gefitinib as first-line treatment for patients with EGFR-mutation-positive non-small-cell lung cancer (ARCHER 1050): A randomised, open-label, phase 3 trial. Lancet Oncol. 2017, 18, 1454-1466. [CrossRef]

50. Recondo, G.; Facchinetti, F.; Olaussen, K.A.; Besse, B.; Friboulet, L. Making the first move in EGFR-driven or ALK-driven NSCLC: First-generation or next-generation TKI? Nat. Rev. Clin. Oncol. 2018, 15, 694-708. [CrossRef]

51. Yang, J.J.; Zhou, Q.; Yan, H.H.; Zhang, X.C.; Chen, H.J.; Tu, H.Y.; Wang, Z.; Xu, C.R.; Su, J.; Wang, B.C.; et al. A phase III randomised controlled trial of erlotinib vs. gefitinib in advanced non-small cell lung cancer with EGFR mutations. Br. J. Cancer 2017, 116, 568-574. [CrossRef]

52. Park, K.; Tan, E.H.; O’Byrne, K.; Zhang, L.; Boyer, M.; Mok, T.; Hirsh, V.; Yang, J.C.; Lee, K.H.; Lu, S.; et al. Afatinib versus gefitinib as first-line treatment of patients with EGFR mutation-positive non-small-cell lung cancer (LUX-Lung 7): A phase 2B, open-label, randomised controlled trial. Lancet Oncol. 2016, 17, 577-589. [CrossRef]

53. Yu, H.A.; Arcila, M.E.; Rekhtman, N.; Sima, C.S.; Zakowski, M.F.; Pao, W.; Kris, M.G.; Miller, V.A.; Ladanyi, M.; Riely, G.J. Analysis of tumor specimens at the time of acquired resistance to EGFR-TKI therapy in 155 patients with EGFR-mutant lung cancers. Clin. Cancer Res. 2013, 19, 2240-2247. [CrossRef]

54. Yun, C.H.; Mengwasser, K.E.; Toms, A.V.; Woo, M.S.; Greulich, H.; Wong, K.K.; Meyerson, M.; Eck, M.J. The T790M mutation in EGFR kinase causes drug resistance by increasing the affinity for ATP. Proc. Natl. Acad. Sci. USA 2008, 105, 2070-2075. [CrossRef] [PubMed]

55. Wang, S.; Yan, B.; Zhang, Y.; Xu, J.; Qiao, R.; Dong, Y.; Zhang, B.; Zhao, Y.; Zhang, L.; Qian, J.; et al. Different characteristics and survival in non-small cell lung cancer patients with primary and acquired EGFR T790M mutation. Int. J. Cancer 2019, 144, 2880-2886. [CrossRef] [PubMed]

56. Mok, T.S.; Wu, Y.L.; Ahn, M.J.; Garassino, M.C.; Kim, H.R.; Ramalingam, S.S.; Shepherd, F.A.; He, Y.; Akamatsu, H.; Theelen, W.S.; et al. Osimertinib or Platinum-Pemetrexed in EGFR T790M-Positive Lung Cancer. New Engl. J. Med. 2017, 376, 629-640. [CrossRef] [PubMed]

57. Yang, J.C.; Ahn, M.J.; Kim, D.W.; Ramalingam, S.S.; Sequist, L.V.; Su, W.C.; Kim, S.W.; Kim, J.H.; Planchard, D.; Felip, E.; et al. Osimertinib in Pretreated T790M-Positive Advanced Non-Small-Cell Lung Cancer: AURA Study Phase II Extension Component. J. Clin. Oncol. 2017, 35, 1288-1296. [CrossRef]

58. Goss, G.; Tsai, C.M.; Shepherd, F.A.; Bazhenova, L.; Lee, J.S.; Chang, G.C.; Crino, L.; Satouchi, M.; Chu, Q.; Hida, T.; et al. Osimertinib for pretreated EGFR Thr790Met-positive advanced non-small-cell lung cancer (AURA2): A multicentre, open-label, single-arm, phase 2 study. Lancet Oncol. 2016, 17, 1643-1652. [CrossRef]

59. Mitsudomi, T.; Ahn, M.; Bazhenova, L.; Blackhall, F.; Hida, T.; Majem Tarruella, M.; Vowler, S.L.; Laus, G.; Janne, P.A.; Yang, J.C. Overall survival (OS) in patients (pts) with EGFR T790M-positive advanced non-small cell lung cancer (NSCLC) treated with osimertinib: Results from two phase II studies. Ann. Oncol. 2017, 28 (Suppl. 5), v460-v496. [CrossRef]

60. Wu, Y.L.; Tong, R.Z.; Zhang, Y.; Hu, B.B.; Zhen, K.; Zhao, Q.; Zhou, X.J.; Ding, Z.Y.; Peng, F.; Gong, Y.L. Detecting T790M mutation of tissue and plasma ctDNA samples by ARMS in EGFR-mutant NSCLC patients after disease progression. J. Clin. Oncol. 2017, 35, e20625. [CrossRef]

61. Oxnard, G.R.; Thress, K.S.; Alden, R.S.; Lawrance, R.; Paweletz, C.P.; Cantarini, M.; Yang, J.C.; Barrett, J.C.; Janne, P.A. Association Between Plasma Genotyping and Outcomes of Treatment With Osimertinib (AZD9291) in Advanced Non-Small-Cell Lung Cancer. J. Clin. Oncol. 2016, 34, 3375-3382. [CrossRef] 
62. Eberlein, C.A.; Stetson, D.; Markovets, A.A.; Al-Kadhimi, K.J.; Lai, Z.; Fisher, P.R.; Meador, C.B.; Spitzler, P.; Ichihara, E.; Ross, S.J.; et al. Acquired Resistance to the Mutant-Selective EGFR Inhibitor AZD9291 Is Associated with Increased Dependence on RAS Signaling in Preclinical Models. Cancer Res. 2015, 75, 2489-2500. [CrossRef]

63. Ramalingam, S.S.; Yang, J.C.; Lee, C.K.; Kurata, T.; Kim, D.W.; John, T.; Nogami, N.; Ohe, Y.; Mann, H.; Rukazenkov, Y.; et al. Osimertinib As First-Line Treatment of EGFR Mutation-Positive Advanced Non-Small-Cell Lung Cancer. J. Clin. Oncol. 2018, 36, 841-849. [CrossRef]

64. Soria, J.C.; Ohe, Y.; Vansteenkiste, J.; Reungwetwattana, T.; Chewaskulyong, B.; Lee, K.H.; Dechaphunkul, A.; Imamura, F.; Nogami, N.; Kurata, T.; et al. Osimertinib in Untreated EGFR-Mutated Advanced Non-Small-Cell Lung Cancer. New Engl. J. Med. 2018, 378, 113-125. [CrossRef] [PubMed]

65. Planchard, D.; Boyer, M.J.; Lee, J.S.; Dechaphunkul, A.; Cheema, P.K.; Takahashi, T.; Gray, J.E.; Tiseo, M.; Ramalingam, S.S.; Todd, A.; et al. Postprogression Outcomes for Osimertinib versus Standard-of-Care EGFR-TKI in Patients with Previously Untreated EGFR-mutated Advanced Non-Small Cell Lung Cancer. Clin. Cancer Res. 2019, 25, 2058-2063. [CrossRef]

66. Ramalingam, S.S.; Vansteenkiste, J.; Planchard, D.; Cho, B.C.; Gray, J.E.; Ohe, Y.; Zhou, C.; Reungwetwattana, T.; Cheng, Y.; Chewaskulyong, B.; et al. Overall Survival with Osimertinib in Untreated, EGFR-Mutated Advanced NSCLC. New Engl. J. Med. 2020, 382, 41-50. [CrossRef] [PubMed]

67. Cho, J.H.; Lim, S.H.; An, H.J.; Kim, K.H.; Park, K.U.; Kang, E.J.; Choi, Y.H.; Ahn, M.S.; Lee, M.H.; Sun, J.M.; et al. Osimertinib for Patients With Non-Small-Cell Lung Cancer Harboring Uncommon EGFR Mutations: A Multicenter, Open-Label, Phase II Trial (KCSG-LU15-09). J. Clin. Oncol. 2020, 38, 488-495. [CrossRef] [PubMed]

68. Le, X.; Puri, S.; Negrao, M.V.; Nilsson, M.B.; Robichaux, J.; Boyle, T.; Hicks, J.K.; Lovinger, K.L.; Roarty, E.; Rinsurongkawong, W.; et al. Landscape of EGFR-Dependent and -Independent Resistance Mechanisms to Osimertinib and Continuation Therapy Beyond Progression in EGFR-Mutant NSCLC. Clin. Cancer Res. 2018, 24, 6195-6203. [CrossRef] [PubMed]

69. Sequist, L.V.; Han, J.Y.; Ahn, M.J.; Cho, B.C.; Yu, H.; Kim, S.W.; Yang, J.C.; Lee, J.S.; Su, W.C.; Kowalski, D.; et al. Osimertinib plus savolitinib in patients with EGFR mutation-positive, MET-amplified, non-small-cell lung cancer after progression on EGFR tyrosine kinase inhibitors: Interim results from a multicentre, open-label, phase 1b study. Lancet Oncol. 2020, 21, 373-386. [CrossRef]

70. Nakagawa, K.; Garon, E.B.; Seto, T.; Nishio, M.; Ponce Aix, S.; Paz-Ares, L.; Chiu, C.H.; Park, K.; Novello, S.; Nadal, E.; et al. Ramucirumab plus erlotinib in patients with untreated, EGFR-mutated, advanced non-small-cell lung cancer (RELAY): A randomised, double-blind, placebo-controlled, phase 3 trial. Lancet Oncol. 2019, 20, 1655-1669. [CrossRef]

71. Noronha, V.; Patil, V.M.; Joshi, A.; Menon, N.; Chougule, A.; Mahajan, A.; Janu, A.; Purandare, N.; Kumar, R.; More, S.; et al. Gefitinib Versus Gefitinib Plus Pemetrexed and Carboplatin Chemotherapy in EGFR-Mutated Lung Cancer. J. Clin. Oncol. 2020, 38, 124-136. [CrossRef]

72. Soda, M.; Choi, Y.L.; Enomoto, M.; Takada, S.; Yamashita, Y.; Ishikawa, S.; Fujiwara, S.; Watanabe, H.; Kurashina, K.; Hatanaka, H.; et al. Identification of the transforming EML4-ALK fusion gene in non-small-cell lung cancer. Nature 2007, 448, 561-566. [CrossRef]

73. Shaw, A.T.; Yeap, B.Y.; Mino-Kenudson, M.; Digumarthy, S.R.; Costa, D.B.; Heist, R.S.; Solomon, B.; Stubbs, H.; Admane, S.; McDermott, U.; et al. Clinical features and outcome of patients with non-small-cell lung cancer who harbor EML4-ALK. J. Clin. Oncol. 2009, 27, 4247-4253. [CrossRef]

74. Choi, Y.L.; Takeuchi, K.; Soda, M.; Inamura, K.; Togashi, Y.; Hatano, S.; Enomoto, M.; Hamada, T.; Haruta, H.; Watanabe, H.; et al. Identification of novel isoforms of the EML4-ALK transforming gene in non-small cell lung cancer. Cancer Res. 2008, 68, 4971-4976. [CrossRef] [PubMed]

75. Takeuchi, K.; Choi, Y.L.; Soda, M.; Inamura, K.; Togashi, Y.; Hatano, S.; Enomoto, M.; Takada, S.; Yamashita, Y.; Satoh, Y.; et al. Multiplex reverse transcription-PCR screening for EML4-ALK fusion transcripts. Clin. Cancer Res. 2008, 14, 6618-6624. [CrossRef] [PubMed]

76. Chiarle, R.; Voena, C.; Ambrogio, C.; Piva, R.; Inghirami, G. The anaplastic lymphoma kinase in the pathogenesis of cancer. Nat. Rev. Cancer 2008, 8, 11-23. [CrossRef] [PubMed]

77. Koivunen, J.P.; Mermel, C.; Zejnullahu, K.; Murphy, C.; Lifshits, E.; Holmes, A.J.; Choi, H.G.; Kim, J.; Chiang, D.; Thomas, R.; et al. EML4-ALK fusion gene and efficacy of an ALK kinase inhibitor in lung cancer. Clin. Cancer Res. 2008, 14, 4275-4283. [CrossRef] 
78. Shaw, A.T.; Riely, G.J.; Bang, Y.J.; Kim, D.W.; Camidge, D.R.; Solomon, B.J.; Varella-Garcia, M.; Iafrate, A.J.; Shapiro, G.I.; Usari, T.; et al. Crizotinib in ROS1-rearranged advanced non-small-cell lung cancer (NSCLC): Updated results, including overall survival, from PROFILE 1001. Ann. Oncol. 2019, 30, 1121-1126. [CrossRef]

79. Kim, D.W.; Ahn, M.J.; Shi, Y.; De Pas, T.M.; Yang, P.C.; Crinò, R.; Evans, T.L.; Liu, X.; Han, J.Y.; Salgia, R. Results of a global phase II study with crizotinib in advanced ALK-positive non-small cell lung cancer (NSCLC). J. Clin. Oncol. 2012, 30, S7533. [CrossRef]

80. Shaw, A.T.; Kim, D.W.; Nakagawa, K.; Seto, T.; Crino, L.; Ahn, M.J.; De Pas, T.; Besse, B.; Solomon, B.J.; Blackhall, F.; et al. Crizotinib versus chemotherapy in advanced ALK-positive lung cancer. New Engl. J. Med. 2013, 368, 2385-2394. [CrossRef]

81. Solomon, B.J.; Mok, T.; Kim, D.W.; Wu, Y.L.; Nakagawa, K.; Mekhail, T.; Felip, E.; Cappuzzo, F.; Paolini, J.; Usari, T.; et al. First-line crizotinib versus chemotherapy in ALK-positive lung cancer. New Engl. J. Med. 2014, 371, 2167-2177. [CrossRef]

82. Soria, J.C.; Tan, D.S.W.; Chiari, R.; Wu, Y.L.; Paz-Ares, L.; Wolf, J.; Geater, S.L.; Orlov, S.; Cortinovis, D.; Yu, C.J.; et al. First-line ceritinib versus platinum-based chemotherapy in advanced ALK-rearranged non-small-cell lung cancer (ASCEND-4): A randomised, open-label, phase 3 study. Lancet 2017, 389, 917-929. [CrossRef]

83. Shaw, A.T.; Kim, T.M.; Crino, L.; Gridelli, C.; Kiura, K.; Liu, G.; Novello, S.; Bearz, A.; Gautschi, O.; Mok, T.; et al. Ceritinib versus chemotherapy in patients with ALK-rearranged non-small-cell lung cancer previously given chemotherapy and crizotinib (ASCEND-5): A randomised, controlled, open-label, phase 3 trial. Lancet Oncol. 2017, 18, 874-886. [CrossRef]

84. Hida, T.; Seto, T.; Horinouchi, H.; Maemondo, M.; Takeda, M.; Hotta, K.; Hirai, F.; Kim, Y.H.; Matsumoto, S.; Ito, M.; et al. Phase II study of ceritinib in alectinib-pretreated patients with anaplastic lymphoma kinase-rearranged metastatic non-small-cell lung cancer in Japan: ASCEND-9. Cancer Sci. 2018, 109, 2863-2872. [CrossRef] [PubMed]

85. Novello, S.; Mazieres, J.; Oh, I.J.; de Castro, J.; Migliorino, M.R.; Helland, A.; Dziadziuszko, R.; Griesinger, F.; Kotb, A.; Zeaiter, A.; et al. Alectinib versus chemotherapy in crizotinib-pretreated anaplastic lymphoma kinase (ALK)-positive non-small-cell lung cancer: Results from the phase III ALUR study. Ann. Oncol. 2018, 29, 1409-1416. [CrossRef] [PubMed]

86. Zhou, C.; Kim, S.W.; Reungwetwattana, T.; Zhou, J.; Zhang, Y.; He, J.; Yang, J.J.; Cheng, Y.; Lee, S.H.; Bu, L.; et al. Alectinib versus crizotinib in untreated Asian patients with anaplastic lymphoma kinase-positive non-small-cell lung cancer (ALESIA): A randomised phase 3 study. Lancet Respir. Med. 2019, 7, 437-446. [CrossRef]

87. Hida, T.; Nokihara, H.; Kondo, M.; Kim, Y.H.; Azuma, K.; Seto, T.; Takiguchi, Y.; Nishio, M.; Yoshioka, H.; Imamura, F.; et al. Alectinib versus crizotinib in patients with ALK-positive non-small-cell lung cancer (J-ALEX): An open-label, randomised phase 3 trial. Lancet 2017, 390, 29-39. [CrossRef]

88. Peters, S.; Camidge, D.R.; Shaw, A.T.; Gadgeel, S.; Ahn, J.S.; Kim, D.W.; Ou, S.I.; Perol, M.; Dziadziuszko, R.; Rosell, R.; et al. Alectinib versus Crizotinib in Untreated ALK-Positive Non-Small-Cell Lung Cancer. New Engl. J. Med. 2017, 377, 829-838. [CrossRef]

89. Camidge, D.R.; Kim, H.R.; Ahn, M.J.; Yang, J.C.; Han, J.Y.; Lee, J.S.; Hochmair, M.J.; Li, J.Y.; Chang, G.C.; Lee, K.H.; et al. Brigatinib versus Crizotinib in ALK-Positive Non-Small-Cell Lung Cancer. New Engl. J. Med. 2018, 379, 2027-2039. [CrossRef]

90. Shaw, A.T.; Felip, E.; Bauer, T.M.; Besse, B.; Navarro, A.; Postel-Vinay, S.; Gainor, J.F.; Johnson, M.; Dietrich, J.; James, L.P.; et al. Lorlatinib in non-small-cell lung cancer with ALK or ROS1 rearrangement: An international, multicentre, open-label, single-arm first-in-man phase 1 trial. Lancet Oncol. 2017, 18, 1590-1599. [CrossRef]

91. Lin, J.J.; Zhu, V.W.; Yoda, S.; Yeap, B.Y.; Schrock, A.B.; Dagogo-Jack, I.; Jessop, N.A.; Jiang, G.Y.; Le, L.P.; Gowen, K.; et al. Impact of EML4-ALK Variant on Resistance Mechanisms and Clinical Outcomes in ALK-Positive Lung Cancer. J. Clin. Oncol. 2018, 36, 1199-1206. [CrossRef]

92. Shaw, A.T.; Solomon, B.J.; Besse, B.; Bauer, T.M.; Lin, C.C.; Soo, R.A.; Riely, G.J.; Ou, S.I.; Clancy, J.S.; Li, S.; et al. ALK Resistance Mutations and Efficacy of Lorlatinib in Advanced Anaplastic Lymphoma Kinase-Positive Non-Small-Cell Lung Cancer. J. Clin. Oncol. 2019, 37, 1370-1379. [CrossRef]

93. Solomon, B.J.; Besse, B.; Bauer, T.M.; Felip, E.; Soo, R.A.; Camidge, D.R.; Chiari, R.; Bearz, A.; Lin, C.C.; Gadgeel, S.M.; et al. Lorlatinib in patients with ALK-positive non-small-cell lung cancer: Results from a global phase 2 study. Lancet Oncol. 2018, 19, 1654-1667. [CrossRef]

94. Gainor, J.F.; Dardaei, L.; Yoda, S.; Friboulet, L.; Leshchiner, I.; Katayama, R.; Dagogo-Jack, I.; Gadgeel, S.; Schultz, K.; Singh, M.; et al. Molecular Mechanisms of Resistance to First- and Second-Generation ALK Inhibitors in ALK-Rearranged Lung Cancer. Cancer Discov. 2016, 6, 1118-1133. [CrossRef] [PubMed] 
95. Biomarker/ALK Inhibitor Combinations in Treating Patients With Stage IV ALK Positive Non-squamous Non-small Cell Lung Cancer (The NCI-NRG ALK Protocol). Available online: https://clinicaltrials.gov/ct2/ show/NCT03737994 (accessed on 24 April 2020).

96. Landi, L.; Chella, A.; Chiari, R.; Tiseo, M.; Buosi, R.; Dazzi, C.; Gridelli, C.; Barbieri, F.; Delmonte, A.; Fontanini, G.; et al. MA07.06 Crizotinib in ROS1 rearranged or MET deregulated NSCLC: Preliminary results of the METROS trial. J. Thorac. Oncol. 2017, 12, S380-S381. [CrossRef]

97. Bergethon, K.; Shaw, A.T.; Ou, S.H.; Katayama, R.; Lovly, C.M.; McDonald, N.T.; Massion, P.P.; Siwak-Tapp, C.; Gonzalez, A.; Fang, R.; et al. ROS1 rearrangements define a unique molecular class of lung cancers. J. Clin. Oncol 2012, 30, 863-870. [CrossRef] [PubMed]

98. Lim, S.M.; Kim, H.R.; Lee, J.S.; Lee, K.H.; Lee, Y.G.; Min, Y.J.; Cho, E.K.; Lee, S.S.; Kim, B.S.; Choi, M.Y.; et al. Open-Label, Multicenter, Phase II Study of Ceritinib in Patients With Non-Small-Cell Lung Cancer Harboring ROS1 Rearrangement. J. Clin. Oncol. 2017, 35, 2613-2618. [CrossRef]

99. Solomon, B.J.; Martini, J.; Ou, S.I.; Chiari, R.; Soo, R.A.; Bearx, A.; Li, S.; Thurm, H.; Lin, C.; Riely, G.J. Efficacy of lorlatinib in patients (pts) with ROS1-positive advanced non-small cell lung cancer (NSCLC) and ROS1 kinase domain mutations. Lancet Oncol. 2018, 19, 1654-1667. [CrossRef]

100. Shaw, A.T.; Solomon, B.J.; Chiari, R.; Riely, G.J.; Besse, B.; Soo, R.A.; Kao, S.; Lin, C.C.; Bauer, T.M.; Clancy, J.S.; et al. Lorlatinib in advanced ROS1-positive non-small-cell lung cancer: A multicentre, open-label, single-arm, phase 1-2 trial. Lancet Oncol. 2019, 20, 1691-1701. [CrossRef]

101. Drilon, A.; Siena, S.; Dziadziuszko, R.; Barlesi, F.; Krebs, M.G.; Shaw, A.T.; de Braud, F.; Rolfo, C.; Ahn, M.J.; Wolf, J.; et al. Entrectinib in ROS1 fusion-positive non-small-cell lung cancer: Integrated analysis of three phase 1-2 trials. Lancet Oncol. 2020, 21, 261-270. [CrossRef]

102. Cho, B.C.; Drilon, A.E.; Doebele, R.C.; Kim, D.W.; Lin, J.J.; Lee, J.; Ahn, M.J.; Zhu, V.W.; Ejadi, S.; Camidge, D.R.; et al. Safety and preliminary clinical activity of repotrectinib in patients with advanced ROS1 fusion-positive non-small cell lung cancer (TRIDENT-1 study). J. Clin. Oncol. 2019, 37, S9011. [CrossRef]

103. Davies, H.; Bignell, G.R.; Cox, C.; Stephens, P.; Edkins, S.; Clegg, S.; Teague, J.; Woffendin, H.; Garnett, M.J.; Bottomley, W.; et al. Mutations of the BRAF gene in human cancer. Nature 2002, 417, 949-954. [CrossRef]

104. Cardarella, S.; Ogino, A.; Nishino, M.; Butaney, M.; Shen, J.; Lydon, C.; Yeap, B.Y.; Sholl, L.M.; Johnson, B.E.; Janne, P.A. Clinical, pathologic, and biologic features associated with BRAF mutations in non-small cell lung cancer. Clin. Cancer Res. 2013, 19, 4532-4540. [CrossRef]

105. Planchard, D.; Kim, T.M.; Mazieres, J.; Quoix, E.; Riely, G.; Barlesi, F.; Souquet, P.J.; Smit, E.F.; Groen, H.J.; Kelly, R.J.; et al. Dabrafenib in patients with BRAF(V600E)-positive advanced non-small-cell lung cancer: A single-arm, multicentre, open-label, phase 2 trial. Lancet Oncol. 2016, 17, 642-650. [CrossRef]

106. Hyman, D.M.; Puzanov, I.; Subbiah, V.; Faris, J.E.; Chau, I.; Blay, J.Y.; Wolf, J.; Raje, N.S.; Diamond, E.L.; Hollebecque, A.; et al. Vemurafenib in Multiple Nonmelanoma Cancers with BRAF V600 Mutations. New Engl. J. Med. 2015, 373, 726-736. [CrossRef] [PubMed]

107. Planchard, D.; Besse, B.; Groen, H.J.M.; Souquet, P.J.; Quoix, E.; Baik, C.S.; Barlesi, F.; Kim, T.M.; Mazieres, J.; Novello, S.; et al. Dabrafenib plus trametinib in patients with previously treated BRAF(V600E)-mutant metastatic non-small cell lung cancer: An open-label, multicentre phase 2 trial. Lancet Oncol. 2016, 17, 984-993. [CrossRef]

108. Planchard, D.; Smit, E.F.; Groen, H.J.M.; Mazieres, J.; Besse, B.; Helland, A.; Giannone, V.; D'Amelio, A.M., Jr.; Zhang, P.; Mookerjee, B.; et al. Dabrafenib plus trametinib in patients with previously untreated BRAF(V600E)-mutant metastatic non-small-cell lung cancer: An open-label, phase 2 trial. Lancet Oncol. 2017, 18, 1307-1316. [CrossRef]

109. Drilon, A.E.; Camidge, D.R.; Ou, S.H.; Clark, J.W.; Socinski, M.A.; Weiss, J.; Riely, G.; Winter, M.; Wang, S.C.; Monti, K.; et al. Efficacy and safety of crizotinib in patients (pts) with advanced MET exon 14-altered non-small cell lung cancer (NSCLC). J. Clin. Oncol. 2017, 4, S108. [CrossRef]

110. Wolf, K.; Seto, T.; Han, J.Y.; Reguart, N.; Garon, E.B.; Groen, H.J.M.; Tan, D.S.; Hida, T.; De Jonge, M.J.; Orlov, S.V.; et al. Capmatinib (INC280) in MET $\Delta$ ex14-mutated advanced non-small cell lung cancer (NSCLC): Efficacy data from the phase II GEOMETRY mono-1 study. J. Clin. Oncol. 2019, 37, S9004. [CrossRef]

111. Wu, Y.L.; Zhang, L.; Kim, D.W.; Liu, X.; Lee, D.H.; Yang, J.C.; Ahn, M.J.; Vansteenkiste, J.F.; Su, W.C.; Felip, E.; et al. Phase Ib/II Study of Capmatinib (INC280) Plus Gefitinib After Failure of Epidermal Growth Factor Receptor (EGFR) Inhibitor Therapy in Patients With EGFR-Mutated, MET Factor-Dysregulated Non-Small-Cell Lung Cancer. J. Clin. Oncol. 2018, 36, 3101-3109. [CrossRef] 
112. Paik, P.K.; Veillon, R.; Cortot, A.B.; Felip, E.; Sakai, H.; Mazieres, J.; Griesinger, F.; Horn, L.; Senellart, H.; Van Meerbeeck, J.P.; et al. Phase II study of tepotinib in NSCLC patients with METex14 mutations. J. Clin. Oncol. 2019, 37, S9005. [CrossRef]

113. Wang, R.; Hu, H.; Pan, Y.; Li, Y.; Ye, T.; Li, C.; Luo, X.; Wang, L.; Li, H.; Zhang, Y.; et al. RET fusions define a unique molecular and clinicopathologic subtype of non-small-cell lung cancer. J. Clin. Oncol. 2012, 30, 4352-4359. [CrossRef]

114. Ju, Y.S.; Lee, W.C.; Shin, J.Y.; Lee, S.; Bleazard, T.; Won, J.K.; Kim, Y.T.; Kim, J.I.; Kang, J.H.; Seo, J.S. A transforming KIF5B and RET gene fusion in lung adenocarcinoma revealed from whole-genome and transcriptome sequencing. Genome Res. 2012, 22, 436-445. [CrossRef]

115. Gautschi, O.; Milia, J.; Filleron, T.; Wolf, J.; Carbone, D.P.; Owen, D.; Camidge, R.; Narayanan, V.; Doebele, R.C.; Besse, B.; et al. Targeting RET in Patients With RET-Rearranged Lung Cancers: Results From the Global, Multicenter RET Registry. J. Clin. Oncol. 2017, 35, 1403-1410. [CrossRef] [PubMed]

116. Oxnard, G.; Subbiah, V.; Park, K.; Bauer, T.; Wirth, L.; Velcheti, V.; Shah, M.; Besse, B.; Boni, V.; Reckamp, K.; et al. Clinical activity of LOXO-292, a highly selective RET inhibitor, in patients with RET fusion+ non-small cell lung cancer. J. Thorac. Oncol. 2018, 13, 349-350. [CrossRef]

117. Drilon, A.; Oxnard, G.; Wirth, L.; Besse, B.; Gautschi, O.; Tan, S.W.D.; Loong, H.; Bauer, T.; Kim, Y.J.; Horiike, A.; et al. Registrational results of LIBRETTO-001: A phase1/2 trial of Selpercatinib (LOXO-292) in patients with RET fusion-positive lung cancers. In Proceedings of the World Conference in Lung Cancer, Barcelona, Spain, 7-10 September 2019.

118. Gainor, J.F.; Lee, D.H.; Curigliano, G.; Doebele, R.C.; Kim, D.W.; Baik, C.S.; Tan, D.S.W.; Lopes, G.; Gadgeel, S.M.; Cassier, P.A.; et al. Clinical activity and tolerability of BLU-667, a highly potent and selective RET inhibitor, in patients (pts) with advanced RET-fusion+ non-small cell lung cancer (NSCLC). J. Clin. Oncol. 2019, 37, 9008. [CrossRef]

119. Nakagawara, A. Trk receptor tyrosine kinases: A bridge between cancer and neural development. Cancer Lett. 2001, 169, 107-114. [CrossRef]

120. Vaishnavi, A.; Capelletti, M.; Le, A.T.; Kako, S.; Butaney, M.; Ercan, D.; Mahale, S.; Davies, K.D.; Aisner, D.L.; Pilling, A.B.; et al. Oncogenic and drug-sensitive NTRK1 rearrangements in lung cancer. Nat. Med. 2013, 19, 1469-1472. [CrossRef]

121. Farago, A.; Kummar, S.; Ibabekci, S.; Corsi-Travali, S.; Cruickshank, S.; Cox, M.; Ku, N.; Drilon, A. Rapid, robust and durable responses to Larotrectinib in patients with TRK fusion non-small cell lung Cancer. J. Thorac. Oncol. 2018, 13, 597-598. [CrossRef]

122. Drilon, A.; Nagasubramanian, R.; Blake, J.F.; Ku, N.; Tuch, B.B.; Ebata, K.; Smith, S.; Lauriault, V.; Kolakowski, G.R.; Brandhuber, B.J.; et al. A next-generation TRK kinase inhibitor overcomes acquired resistance to prior TRK kinase inhibition in patients with TRK fusion-positive solid tumors. Cancer Discov. 2017, 7, 963-972. [CrossRef]

123. Demetri, G.D.; Paz-Ares, L.; Farago, A.F.; Liu, S.V.; Chawla, S.P.; Tosi, D.; Kim, E.S.; Blakely, C.; Krauss, J.C.; Sigal, D.; et al. Efficacy and safety of entrectinib in patients with NTRK fusion-positive (NTRK-fp) tumors: Pooled analysis of STARTRK-2, STARTRK-1 and ALKA-372-001. Ann. Oncol. 2018, 29, viii713. [CrossRef]

124. Baselga, J.; Swain, S.M. Novel anticancer targets: Revisiting ERBB2 and discovering ERBB3. Nat. Rev. Cancer 2009, 9, 463-475. [CrossRef]

125. Arcila, M.E.; Chaft, J.E.; Nafa, K.; Roy-Chowdhuri, S.; Lau, C.; Zaidinski, M.; Paik, P.K.; Zakowski, M.F.; Kris, M.G.; Ladanyi, M. Prevalence, clinicopathologic associations, and molecular spectrum of ERBB2 (HER2) tyrosine kinase mutations in lung adenocarcinomas. Clin. Cancer Res. 2012, 18, 4910-4918. [CrossRef]

126. Kris, M.G.; Camidge, D.R.; Giaccone, G.; Hida, T.; Li, B.T.; O'Connell, J.; Taylor, I.; Zhang, H.; Arcila, M.E.; Goldberg, Z.; et al. Targeting HER2 aberrations as actionable drivers in lung cancers: Phase II trial of the pan-HER tyrosine kinase inhibitor dacomitinib in patients with HER2-mutant or amplified tumors. Ann. Oncol. 2015, 26, 1421-1427. [CrossRef] [PubMed]

127. Smit, E.F.; Peters, S.; Dziadziuszko, R.; Dafni, U.; Wolf, J.; Wasag, B.; Biernat, W.; Finn, S.; Kammler, R.; Tsourti, Z.; et al. A single-arm phase II trial of afatinib in pretreated patients with advanced NSCLC harboring a HER2 mutation: The ETOP NICHE trial. J. Clin. Oncol. 2017, 35, e9070. [CrossRef]

128. Robichaux, J.P.; Elamin, Y.Y.; Tan, Z.; Carter, B.W.; Zhang, S.; Liu, S.; Li, S.; Chen, T.; Poteete, A.; Estrada-Bernal, A.; et al. Mechanisms and clinical activity of an EGFR and HER2 exon 20-selective kinase inhibitor in non-small cell lung cancer. Nat. Med. 2018, 24, 638-646. [CrossRef] [PubMed] 
129. Li, B.T.; Shen, R.; Buonocore, D.; Olah, Z.T.; Ni, A.; Ginsberg, M.S.; Ulaner, G.A.; Offin, M.; Feldman, D.; Hembrough, T.; et al. Ado-Trastuzumab Emtansine for Patients With HER2-Mutant Lung Cancers: Results From a Phase II Basket Trial. J. Clin. Oncol. 2018, 36, 2532-2537. [CrossRef]

130. De Langen, A.J.; Jebbink, M.; Hashemi, S.M.S.; Kuiper, J.L.; de Bruin-Visser, J.; Monkhorst, K.; Thunnissen, E.; Smit, E.F. Trastuzumab and paclitaxel in patients with EGFR mutated NSCLC that express HER2 after progression on EGFR TKI treatment. Br. J. Cancer 2018, 119, 558-564. [CrossRef]

131. Liu, S.; Li, S.; Hai, J.; Wang, X.; Chen, T.; Quinn, M.M.; Gao, P.; Zhang, Y.; Ji, H.; Cross, D.A.E.; et al. Targeting HER2 Aberrations in Non-Small Cell Lung Cancer with Osimertinib. Clin. Cancer Res. 2018, 24, 2594-2604. [CrossRef]

132. Wang, Y.; Jiang, T.; Qin, Z.; Jiang, J.; Wang, Q.; Yang, S.; Rivard, C.; Gao, G.; Ng, T.L.; Tu, M.M.; et al. HER2 exon 20 insertions in non-small-cell lung cancer are sensitive to the irreversible pan-HER receptor tyrosine kinase inhibitor pyrotinib. Ann. Oncol. 2019, 30, 447-455. [CrossRef]

(C) 2020 by the authors. Licensee MDPI, Basel, Switzerland. This article is an open access article distributed under the terms and conditions of the Creative Commons Attribution (CC BY) license (http://creativecommons.org/licenses/by/4.0/). 